\title{
Magmatism of the Kenya Rift Valley: a review
}

\author{
Ray Macdonald
}

\begin{abstract}
Tertiary-Recent magmatism in the Kenya Rift Valley was initiated c. $35 \mathrm{Ma}$, in the northern part of Kenya. Initiation of magmatism then migrated southwards, reaching northern Tanzania by 5-8 Ma. This progression was accompanied by a change in the nature of the lithosphere, from rocks of the Panafrican Mozambique mobile belt through reworked craton margin to rigid, Archaean craton. Magma volumes and the geochemistry of mafic volcanic rocks indicate that magmatism has resulted from the interaction with the lithosphere of melts and/or fluids from one or more mantle plumes. Whilst the plume(s) may have been characterised by an ocean island basalttype component, the chemical signature of this component has everywhere been heavily overprinted by heterogeneous lithospheric mantle. Primary mafic melts have fractionated over a wide range of crustal pressures to generate suites resulting in trachytic (silica-saturated and -undersaturated) and phonolitic residua. Various Neogene trachytic and phonolitic flood sequences may alternatively have resulted from volatile-induced partial melting of underplated mafic rocks. High-level partial melting has generated peralkaline rhyolites in the south-central rift. Kenyan magmatism may, at some future stage, show an increasing plume signature, perhaps associated ultimately with continental break-up.
\end{abstract}

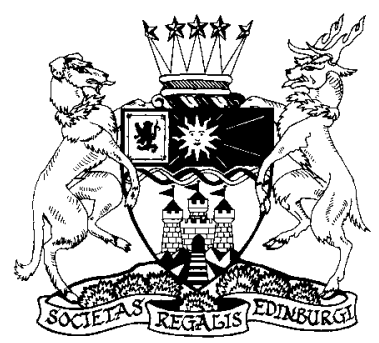

KEY WORDS: Plume-lithosphere interactions

The Red Sea and the Gulf of Aden are two arms of a postulated triple junction centred on the Afar region (Fig. 1). Oceanic crust began to form under these arms $c$. $10 \mathrm{Ma}$. The third arm, the East African Rift System (EARS), extends southwards through Ethiopia, Kenya and Tanzania into Mozambique. Whilst lithospheric extension is occurring beneath the EARS, the rift has not developed to the stage of ocean crust formation. The EARS has come to be seen, therefore, as a prime location in which to investigate the early stages of continental break-up.

This review focuses on the magmatism of the Kenya Rift section, used here to indicate that section of the EARS extending from northern Kenya to northern Tanzania. The primary aim is to demonstrate the complex polybaric evolutionary history of the magmatism, starting with the postulated plume-induced generation of primary magmas by variable degrees of partial melting of heterogeneous, metasomatised lithosphere, through to generation of salic magmas by assimilation-crystal fractionation processes over a range of crustal pressures and by partial melting of crustal protoliths, also over a range of pressures.

\section{Magmatism of the Kenya Rift}

Volcanism in the rift started c. 35-30 Ma in the Turkana region of northern Kenya (Fig. 1). This was followed by normal faulting and extension, estimated currently to be $35-40 \mathrm{~km}$, which corresponds to a stretching $(\beta$-) factor of 1.6 (Hendrie et al. 1994; Mechie et al. 1997). Since its inception, magmatism has subsequently migrated southwards with time, reaching northern Tanzania $c$. 5-8 Ma. Extension in the central and southern parts of the rift also started later than further $\mathrm{N}$, c. $10 \mathrm{Ma}$, and has stretched the crust and lithospheric mantle by c. $10 \mathrm{~km}$ ( $\beta$-factor of 1.1-1.2).

The volume of mafic magma, including underplated material, generated in the Kenya Rift since the Oligocene has been estimated at $924,000 \mathrm{~km}^{3}$ (Latin et al. 1993). This volume is too large to have been produced entirely within (anhydrous) lithosphere, especially since the results of geochemical modelling provide good evidence for small melt fractions during mantle melting (Latin et al. 1993; Macdonald 1994; Macdonald et al. 2001), and the melt zone must have been actively fed by upwelling mantle material (Latin et al. 1993). The low

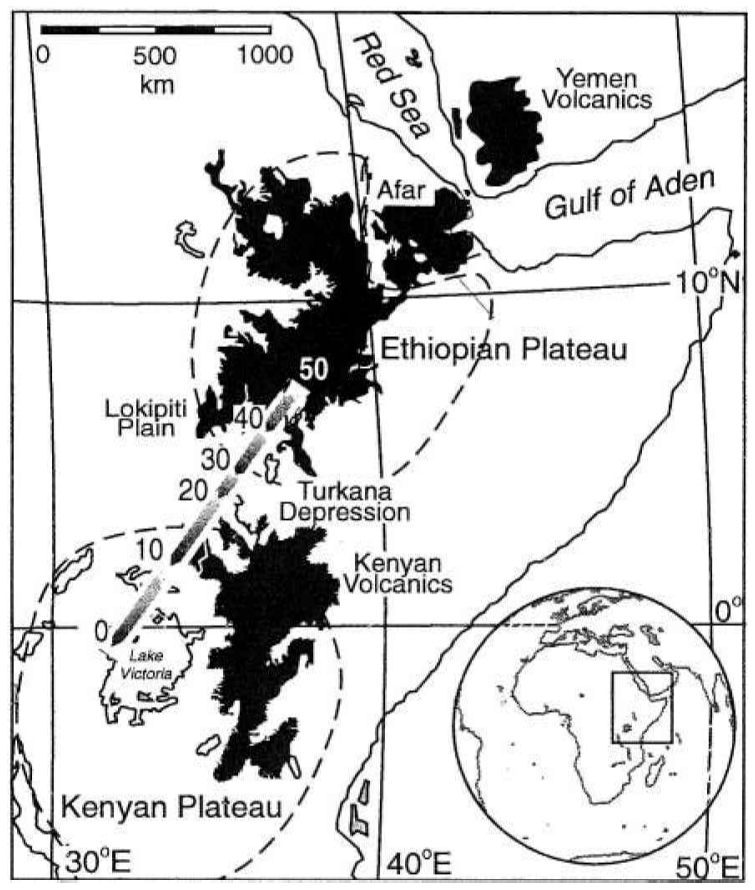

Figure 1 Location map of the Ethiopian and Kenyan plateaux (dashed lines) and of Cenozoic volcanic rocks of the East African Rift System (black). The arrow shows the apparent migration as a result of plate movements of a mantle plume currently centred on Lake Victoria. From Macdonald et al. (2001). 
extension rates, the lengthy duration of the magmatism (c. 35 million years), and the fact that volcanism pre-dated faulting by a few million years in both the northern and southern parts of the rift (Morley et al. 1992; Smith 1994; Ebinger et al. 2000) are consistent with the petrological evidence that elevated mantle temperatures were required in magma generation. The potential temperature of the anomalously hot mantle beneath the axial part of the rift may be as high as $1500^{\circ} \mathrm{C}$ (Mechie et al. 1997); in contrast, Henjes-Kunst \& Altherr (1992) assumed a potential temperature of $1280^{\circ} \mathrm{C}$ beneath volcanic fields on the eastern flanks of the rift system.
The southerly propagation of magmatism was accompanied by a change in the nature of the lithosphere. The basement geology of the rift (Fig. 2) can be divided into three blocks or domains, striking approximately NW-SE (Smith \& Mosley 1993). The oldest, and most southerly, is the Archaean Tanzanian craton, dating back to 2.6-2.9 Ga. To the $\mathrm{N}$ are the Panafrican Proterozoic rocks of the Mozambique mobile belt (800-400 Ma). In an intermediate zone, the margins of the craton were reworked, overthrust and buried by rocks of the mobile belt during a late Proterozoic collisional event.
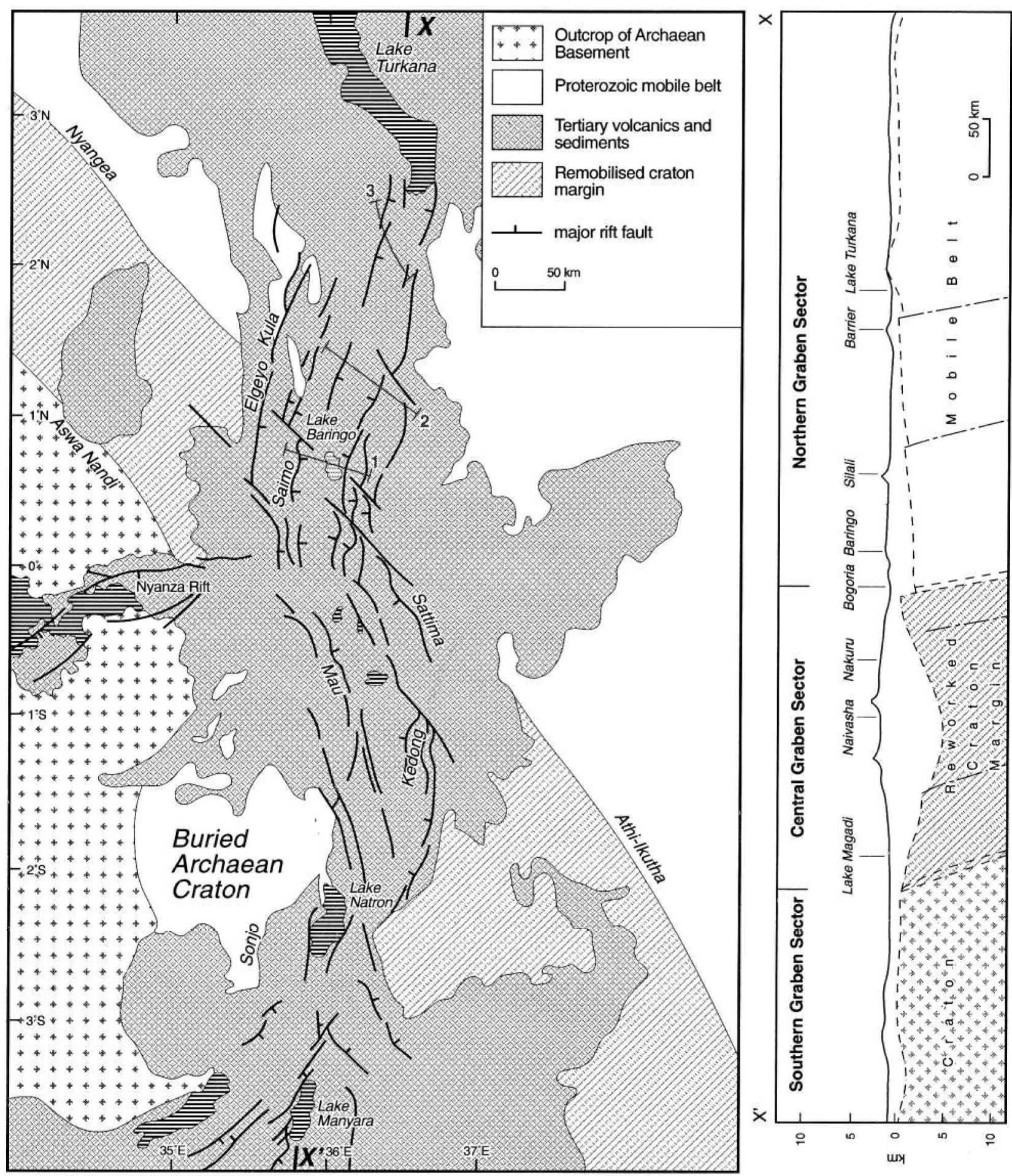

Figure 2 Structural framework and basement domains of the Kenya rift (from Macdonald et al. 2001, much simplified from Smith \& Mosley 1993): (a) thick lines are major faults; (b) N-S profile of estimated depth to basement along line of rift between $\mathrm{X}-\mathrm{X}^{\prime}$ (in a). 
The lithological heterogeneity, with a contrast between the cold, thick, rigid Archaean lithosphere and the thinner, anisotropic, warmer, mobile belt lithosphere, has strongly influenced the rift's development (Smith \& Mosley 1993; Ebinger et al. 1997). For example, reactivation of the thrusts and shear zones affecting the reworked craton margin has controlled the location and geometry of graben structures and the emplacement of magmas since early Miocene times (Smith \& Mosley 1993; Smith 1994). Indeed, the rift is currently propagating along the old suture zone (Smith 1994; Birt et al. 1997).

Macdonald et al. (1994b) argued that the results of a variety of geophysical and geochemical methods were consistent with a variation of lithosphere thickness from some $150 \mathrm{~km}$ under the craton to $100 \mathrm{~km}$ beneath the mobile belt on the flanks to $50-60 \mathrm{~km}$ under the rift axis. Using petrological evidence, Le Roex et al. (2001) suggested that the lithosphere beneath the southern Kenya rift is at least $75 \mathrm{~km}$ thick, precluding interpretations of gravity data which call for asthenospheric upwelling to depths as shallow as the crust-mantle interface (Birt et al. 1997; Simiyu \& Keller 1997).

\section{Deep crustal structure}

Summaries of the deep structure of the crust beneath the rift and its relationship to magmatism may be found in Smith (1994), Macdonald (1994), Macdonald et al. (1994b, 2001), Mechie et al. (1997) and Mussett \& Khan (2000). More detailed accounts, particularly of geophysical studies, can be found in two special issues of Tectonophysics (Prodehl et al. 1994; Fuchs et al. 1997).

Combined seismic refraction and wide-angle reflection profiling has shown that there are significant variations in the thickness of the crust both along and across the rift axis (Fig. 3). Along the axis, crustal thickness varies from $35 \mathrm{~km}$ in the $\mathrm{S}$ beneath Lake Naivasha (Fig. 4) to $20 \mathrm{~km}$ in the $\mathrm{N}$ beneath Lake Turkana. The northwards decrease is accompanied by a decrease in surface topography (from $2-3 \mathrm{~km}$ to $800 \mathrm{~m}$ high), and increases in the width of the rift (from 50$75 \mathrm{~km}$ to $150-200 \mathrm{~km}$ ) and in estimates of the total amount of surface extension $(5-10 \mathrm{~km}$ in the $\mathrm{S}, 35-40 \mathrm{~km}$ in the $\mathrm{N})$. Bouguer gravity changes from $-200-250 \mathrm{mGal}$ in the $\mathrm{S}$ to $-50 \mathrm{mGal}$ in the $\mathrm{N}$, accompanying a variation in crustal thickness along the rift axis (Mechie et al. 1994). The variation
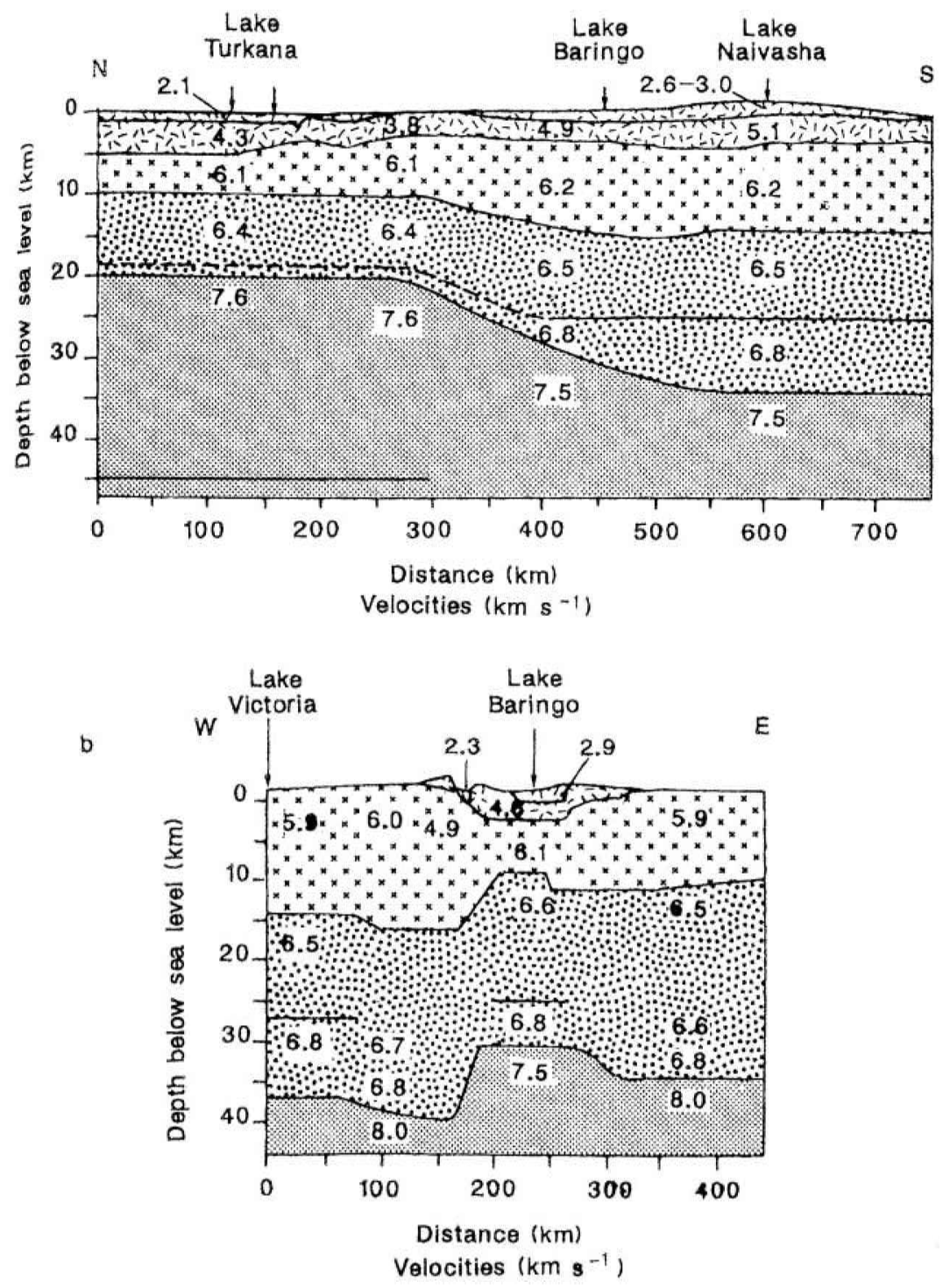

Figure 3 Seismic models of crustal structure (a) along the axis of, and (b) across, the rift (KRISP Working Party 1991, fig. 3). See Figure 4 for locations. 


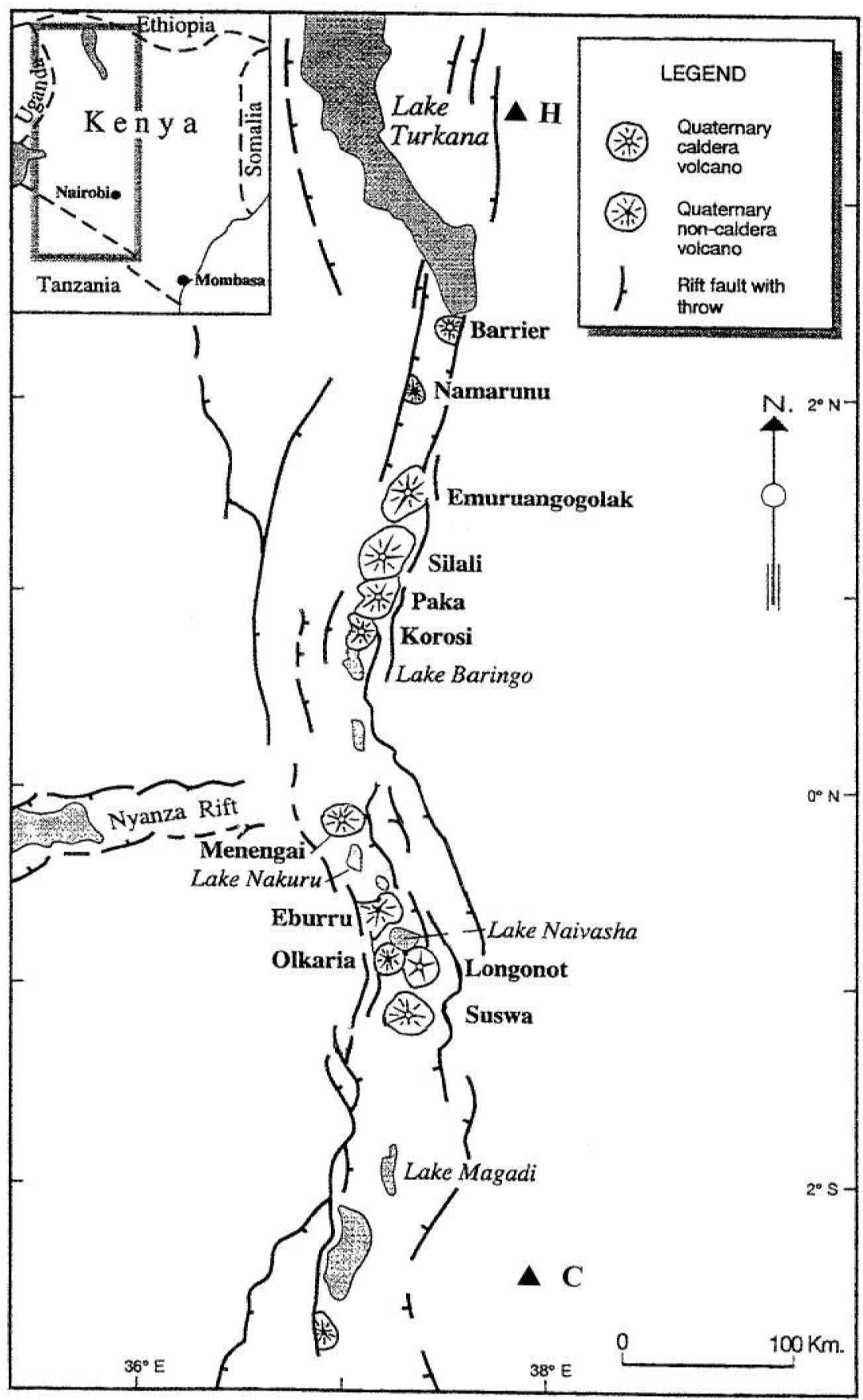

Figure 4 Locality map of selected Quaternary volcanoes in the Kenya rift (slightly modified from Scott \& Skilling 1999); triangles H and C represent the location of the Huri Hills and Chyulu Hills, respectively.

in crustal thickness along the axis correlates with the thickness of a high-velocity layer $\left(6 \cdot 8 \mathrm{~km} \mathrm{~s}^{-1}\right)$ at the base of the crust (Fig. 3a). The crust also thins towards the rift axis, from $\geq 35 \mathrm{~km}$ to $c .30 \mathrm{~km}$ (Fig. $3 \mathrm{~b}$ ).

Along the length of the rift, uppermost mantle $\mathrm{P}_{\mathrm{n}}$ velocities are generally low, $7.5-7.7 \mathrm{~km} \mathrm{~s}^{-1}$. Beneath the flanks, the velocities are normal, at $8 \cdot 0-8 \cdot 2 \mathrm{~km} \mathrm{~s}^{-1}$. The abrupt changes in $P_{n}$ velocities and depth to the Moho at the rift boundaries have been interpreted as an essentially vertical channel of anomalous mantle beneath the rift axis, extending to $160 \mathrm{~km}$ or more (Achauer \& KRISP Teleseismic Working Group 1994; Slack et al. 1994). By calculating the time in which the sharp boundaries would have been smeared out by diffusion, Mechie et al. (1994) concluded that the heat anomaly has been present under the apical part of the south-central rift for the past $20 \mathrm{Ma}$, i.e. for the duration of the Cenozoic volcanism.
The mantle velocity structure has been interpreted to show that the depth to the onset of melting (or to the presence of detectable magma bodies) is $\geq 65 \mathrm{~km}$ beneath the northern part of the rift and somewhat shallower $(45-50 \mathrm{~km})$ beneath Lake Naivasha (Macdonald et al. 1994b).

Superimposed on a c. $250 \mathrm{mGal}$ regional Bouguer anomaly over the EARS is a $-190 \mathrm{mGal}$ gravity high centred on the rift axis, the greatest anomalies coinciding with young $<0.5 \mathrm{Ma}$ central volcanoes on the inner rift floor. Swain (1992) modelled the axial high as resulting from pervasive dyke injection in the central $40 \mathrm{~km}$ of the rift, in which about $22-26 \%$ (or a width of 9-10 km) of the present-day crust, down to a depth of $22 \mathrm{~km}$, consists of intruded material. Some $135,000 \mathrm{~km}^{3}$ of basaltic material can potentially be located in the dyke zone.

Within the Kenya rift, the focus of Miocene-Pliocene volcanism, rifting, the regional Bouguer gravity anomaly and 
the zone of anomalous mantle material coincide with an area of crustal upwarping commonly referred to as the Kenya Dome, the apical region of which lies near Lake Nakuru (Fig. 4; Smith 1994). The Dome is associated with only minor $<1 \mathrm{~km}$ amounts of uplift and is apparently in isostatic equilibrium, supported by the loading of anomalous mantle within the underlying lithosphere. The exact timing and amount of the uplift are difficult to establish. As we shall see, the Kenya Dome was the focus of much of the Neogene magmatism in the south-central part of the rift.

\section{Nature of mantle rocks}

Direct information on the composition of the sub-rift mantle is scanty, due to a scarcity of ultramafic xenoliths. Amphibole and phlogopite have been recorded in xenoliths at Lashaine, Pello Hill and Deeti in northern Tanzania, where they occur on the craton (Dawson \& Smith 1973, 1988; Johnson et al. 1997). Kimberlites from Nyanza province, on cratonic crust in western Kenya, contain garnet-free harzburgite and dunite, with amphibole and lesser amounts of phlogopite (Ito 1986). Henjes-Kunst \& Altherr (1992) recorded phlogopite in a peridotite xenolith from the Chyulu Hills, in the reworked craton margin. Other localities on the eastern flank of the rift, which are in the mobile belt, carry ultramafic xenoliths with either no, or scarce, amphibole and/or phlogopite (Suwa et al. 1975; Henjes-Kunst \& Altherr 1992).

The viability of these xenoliths as analogues for mantle beneath the axial part of the rift may be questionable (Macdonald et al. 1994b). However, detailed geochemical modelling of the generation of primitive alkaline lavas of the Chyulu Hills Volcanic Province, which are characterised by striking depletions in $\mathrm{K}$ relative to other highly incompatible elements, suggest that the source rocks contained amphibole, but not phlogopite (Späth et al. 2000, 2001). Since K depletion is a common, if not ubiquitous, feature of mafic rocks from the axial part of the rift (Macdonald et al. 2001), it seems reasonable to suggest that the mantle sources underlying the mobile belt, at least, comprise four-phase peridotite with small $(\sim 5 \%)$ modal amounts of amphibole.

\section{Range of basaltic magmas}

Baker (1987) reviewed the complexity of magmatic associations in the Kenya Rift, stressing that there is a continuum of mafic compositions from nephelinites through basanites and alkali olivine basalts to hypersthene $(h y)$-normative basalts.

There are important differences in the proportions of more and less silica-undersaturated mafic rocks in each lithospheric domain. Thus in a geochemical study of 185 mafic rocks collected from the axial regions and shoulders of the rift, Macdonald et al. (2001) found that, in the craton, nephelinites and basanites formed $\sim 80 \%$ of the samples and alkali olivine basalts and $h y$-normative basalts $\sim 20 \%$. The corresponding figures for the reworked craton margin were $33 \%$ and $67 \%$, and for the mobile belt $21 \%$ and $79 \%$. Since sampling was not random, these proportions are not strictly applicable but they are consistent with the distribution of magma types based on field mapping (Le Bas 1987; Smith \& Mosley 1993; Smith 1994). Olivine-poor nephelinites (in association with carbonatites) are

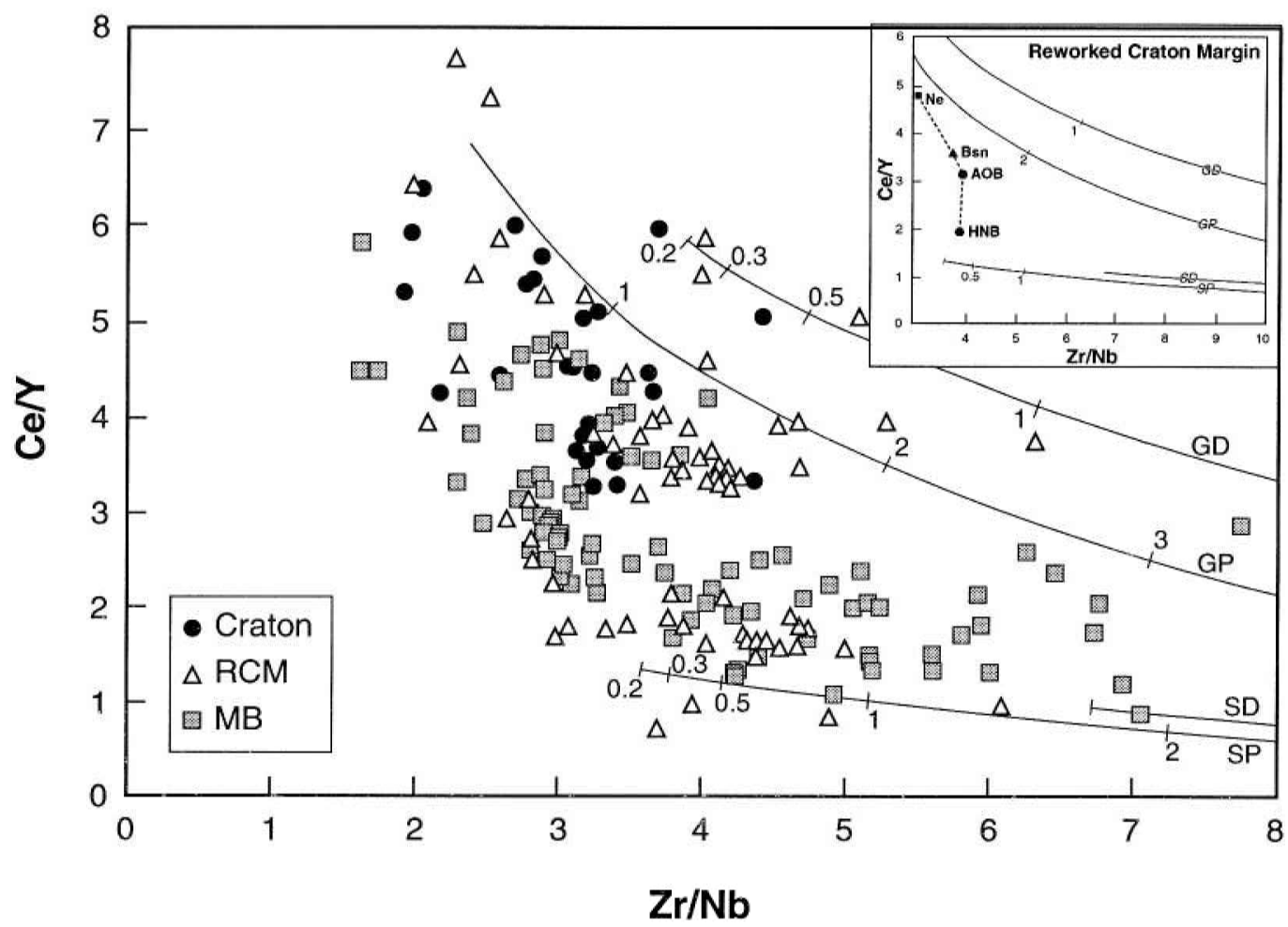

Figure $5 \mathrm{Ce} / \mathrm{Y}-\mathrm{Zr} / \mathrm{Nb}$ plot of mafic volcanic rocks from the axial region and shoulders of the Kenya rift, constructed from a study of 185 samples by Macdonald et al. (2001). The continuous lines are non-modal fractional melting curves calculated by Hardarson \& Fitton (1991) for four mantle compositions: SD, depleted spinel lherzolite; SP, primitive spinel lherzolite; GD, depleted garnet lherzolite; GP, primitive garnet lherzolite. Numbers on lines refer to percentages of melt. In the main diagram, all data are plotted, subdivided by structural setting/lithospheric domain: RCM, reworked craton margin; MB, mobile belt. In the inset, the average compositions of each lithology in the reworked craton margin are shown: Ne, nephelinite; Bsn, basanite; AOB, alkali olivine basalt; HNB, hy-normative basalt. 
largely restricted to the craton and its reworked margins. In the mobile belt, olivine-rich nephelinitic volcanism tends to be associated with large shield volcanoes and high-volume eruptions of alkali olivine and $h y$-normative basalts. The distribution may be related to the presence of thinner lithosphere beneath the mobile belt which, since it had undergone stretching and warming during Cretaceous and Palaeogene rifting events, is more easily eroded and penetrated by rising magmas.

On the basis of trace element evidence, Latin et al. (1993), Macdonald (1994) and Macdonald et al. (2001) inferred that the majority of mafic magmas in the Kenya rift were generated in a melt zone extending across the transition from spinel to garnet peridotite (see also Class et al. 1994; Le Roex et al. 2001). This is exemplified by a $\mathrm{Ce} / \mathrm{Y}$ v. $\mathrm{Zr} / \mathrm{Nb}$ plot (Fig. 5), where the continuous lines represent non-modal fractional melting curves for partial melting of fertile and depleted varieties of spinel and garnet peridotite. Macdonald et al. (2001) noted two particular features of the plot. Firstly, the sequence of the average compositions nephelinite $>$ basanite $>$ alkali basalt $>h y$-normative basalt, as exemplified by rocks of the reworked craton margin (Fig. 5, inset), seems to represent progressively shallower melting (increased component of spinel-facies peridotite), rather than larger degrees of melting. However, the spread of data for each setting suggests variable melt fractions. Latin et al. (1993) reached similar conclusions on the basis of inversion of rare earth element concentrations in rift basalts. Secondly, the craton rocks appear, regardless of magma type, to have been generated at the highest pressures and the mobile belt rocks at the lowest, although there is considerable overlap between magma types.

Confirmatory evidence for the relationship between degree of silica-saturation and pressure of final equilibration comes from major element data, such as $\mathrm{Al}_{2} \mathrm{O}_{3}$ contents and $\mathrm{CaO} / \mathrm{Al}_{2} \mathrm{O}_{3}$ ratios. The ratio is highly pressure-dependent, increasing with increased melting/equilibration pressure, whilst $\mathrm{Al}_{2} \mathrm{O}_{3}$ decreases (Herzberg 1995). Mafic rocks from the axial region of the rift, with $m g$-number $>65$ (where $m g$-number is $100 \times \mathrm{Mg} / \mathrm{Mg} \mathrm{Fe}$ ) and thus potential primary mantle melts, are plotted in Figure 6. Overall, the most silicaundersaturated, nephelinitic, lavas have the highest ratios and lowest $\mathrm{Al}_{2} \mathrm{O}_{3}$ concentrations; the hy-normative basalts have the lowest ratios and highest $\mathrm{Al}_{2} \mathrm{O}_{3}$ concentrations. Lavas of the Huri Hills, on the eastern flank of the rift (Fig. 4; Class et al. 1994), and of the Chyulu Hills volcanic province (Fig. 4;

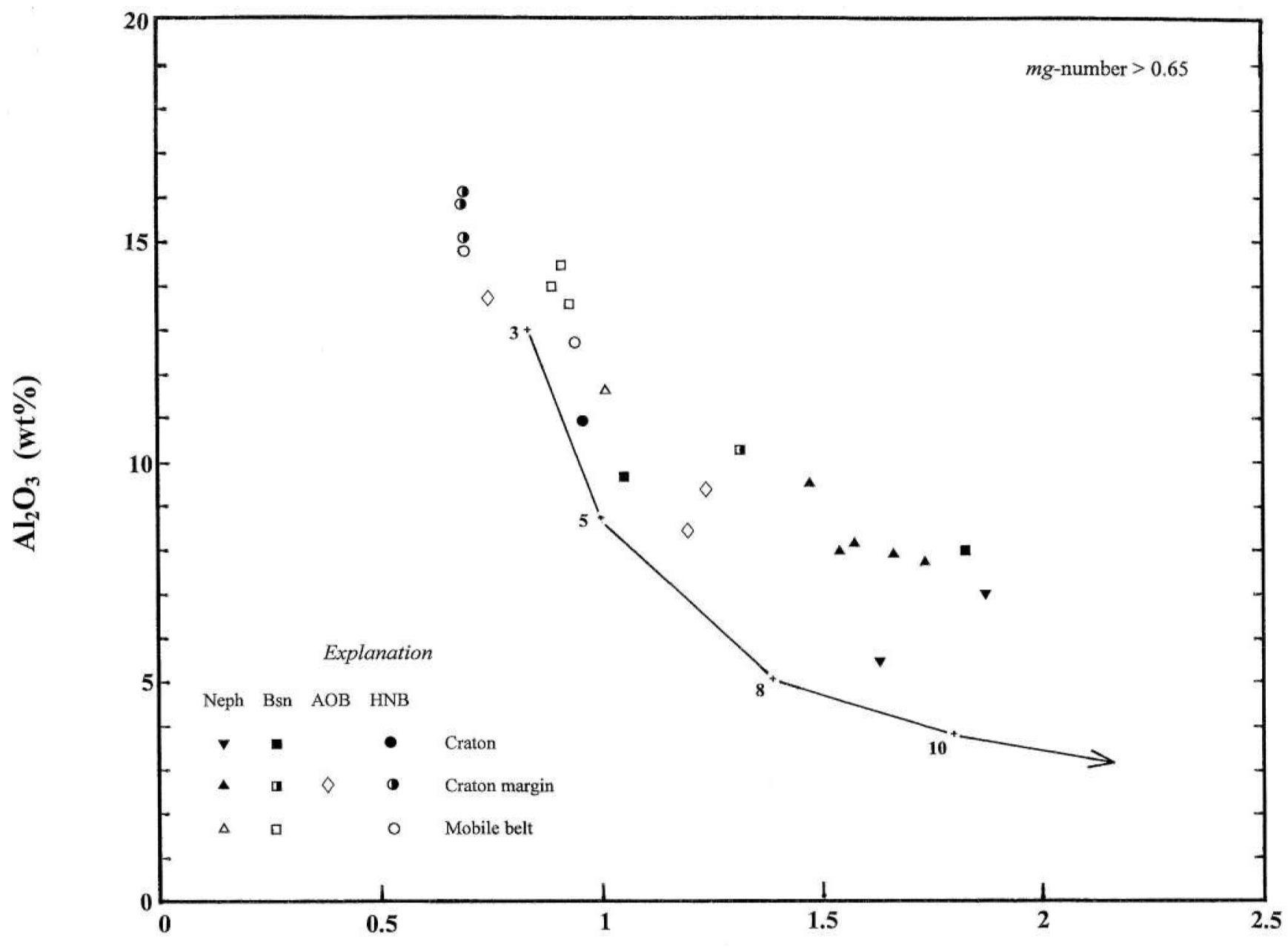

\section{$\mathrm{CaO} / \mathrm{Al}_{2} \mathrm{O}_{3}$}

Figure $6 \mathrm{CaO} / \mathrm{Al}_{2} \mathrm{O}_{3}-\mathrm{Al}_{2} \mathrm{O}_{3}$ plot for rocks from the axial region of the Kenya rift, inferred to be primary mantle melts $(m g$-number $>65)$. Data from Macdonald et al. (2001). Neph, nephelinite; Bsn, basanite; AOB, alkali olivine basalt; HNB, hy-normative basalt. The solid line with crosses represents the compositions of solidus liquids generated by partial melting of fertile peridotite. Numbers refer to pressures in GPa along the solidus (from Herzberg 1995). Compare with Späth et al. (2000, fig. 11) for rocks of the Chyulu Hills Volcanic Province. 
Späth et al. 2000, 2001) show similar relationships. These variations reinforce the strong control exerted by depth (pressure) of melting on degree of silica-undersaturation.

Macdonald et al. (1994b) brought together evidence from mantle structure and composition, basalt equilibration pressures and geophysical information to suggest a relationship between basalt composition, lithospheric thickness and depth to the spinel-garnet transition zone beneath the rift. Beneath the Tanzanian craton, where geothermal gradients are lowest and the lithosphere is $>140 \mathrm{~km}$ thick, a proportion of the basalts show garnet control and degrees of melting may be as low as $<1 \%$. In areas, such as the eastern flanks, where the lithosphere is $c .100 \mathrm{~km}$ thick, melt fractions are in the range $1-$ $3 \%$ and final equilibration takes place over a wider depth range, with many, perhaps most, basalts now showing a spinel control. Lithosphere may locally be as thin as $35 \mathrm{~km}$ under the rift axis. Since the whole spectrum of mafic magmas can be closely associated in the field, and have even been erupted from individual axial volcanoes (Baker 1987), it may be inferred that the melt column is longest under those parts of the rift system where heat flow is greatest and the lithosphere thinnest.

Studies of the spatial and temporal variation in basalt composition along the rift have shown that (1) most sectors of the within-rift sequences show a decrease of silica-undersaturation of mafic lavas with time; and (2) mafic lavas $\mathrm{W}$ and $\mathrm{E}$ of the rift are normally more silica-undersaturated than are lavas within the rift (Lippard \& Truckle 1978; Truckle 1980; Macdonald et al. 2001). These trends are related to two effects: the disappearance of nephelinites from the sequences and an increasing importance of $h y$-normative basalts volumetrically. Since, at any specific locality, magmatism has tended to migrate towards the rift axis, the more silica-saturated rocks are concentrated towards the axis.

Macdonald et al. (2001) have interpreted the time trends to indicate that soon after the commencement of magmatism in each sector of the rift, the melt column extended from the generation depths of nephelinites $\geq 100 \mathrm{~km}$ to those of the hynormative basalts (<50 km; Macdonald et al. 1994b). With time, the column tended to move upwards, with cessation of nephelinitic magmatism and increasing relative abundance of alkali olivine basalts and $h y$-normative basalts. Späth et al. (2000) have also documented a trend of decreasing silicaundersaturation with time in eruptive products of the Quaternary Chyulu Hills Volcanic Province, situated more than $100 \mathrm{~km}$ E of the rift valley in southeastern Kenya (Fig. 4), which they ascribed to an age progressive decrease in the depth of melt generation and a coincident increase in the degree of melting.

There are, however, several exceptions to the general rule that basalt compositions become more silica-saturated with time in specific regions. For example, in the Huri Hills, a Pliocene-Quaternary volcanic field situated on the rift flank E of Lake Turkana (Fig. 4), there was a continuous change from older alkali basalts to younger basanites (Class et al. 1994). The change was accompanied by increasing abundances of incompatible trace elements and is perhaps best explained by a time-dependent systematic decrease in the degree of partial melting and possibly an increase in the depth of partial melting (and thus an increase in the proportion of garnet in the residue). Class et al. (1994) recognise two chemically and isotopically distinct components in the magmas. The first component, most abundant in the older extrusives, has high $\mathrm{Ba} / \mathrm{Nb}, \mathrm{K} / \mathrm{Th}, \quad \mathrm{Sr} / \mathrm{Nd}$ and ${ }^{87} \mathrm{Sr} /{ }^{86} \mathrm{Sr}$ ratios, and low ${ }^{143} \mathrm{Nd} /{ }^{144} \mathrm{Nd}$ and ${ }^{206} \mathrm{~Pb} /{ }^{204} \mathrm{~Pb}$ ratios. It was probably derived from the lithospheric mantle, although a plume source cannot be excluded. The second component, which is more clearly seen in the younger extrusives, is characterised by relatively high ${ }^{206} \mathrm{~Pb} /{ }^{204} \mathrm{~Pb}$ ratios and may be attributed to a mantle plume.

\section{Comparisons with ocean island basalts}

Using trace element data, Macdonald (1994) and Macdonald et al. (2001) showed that there are notable compositional differences between the mafic rocks of the Kenya rift and

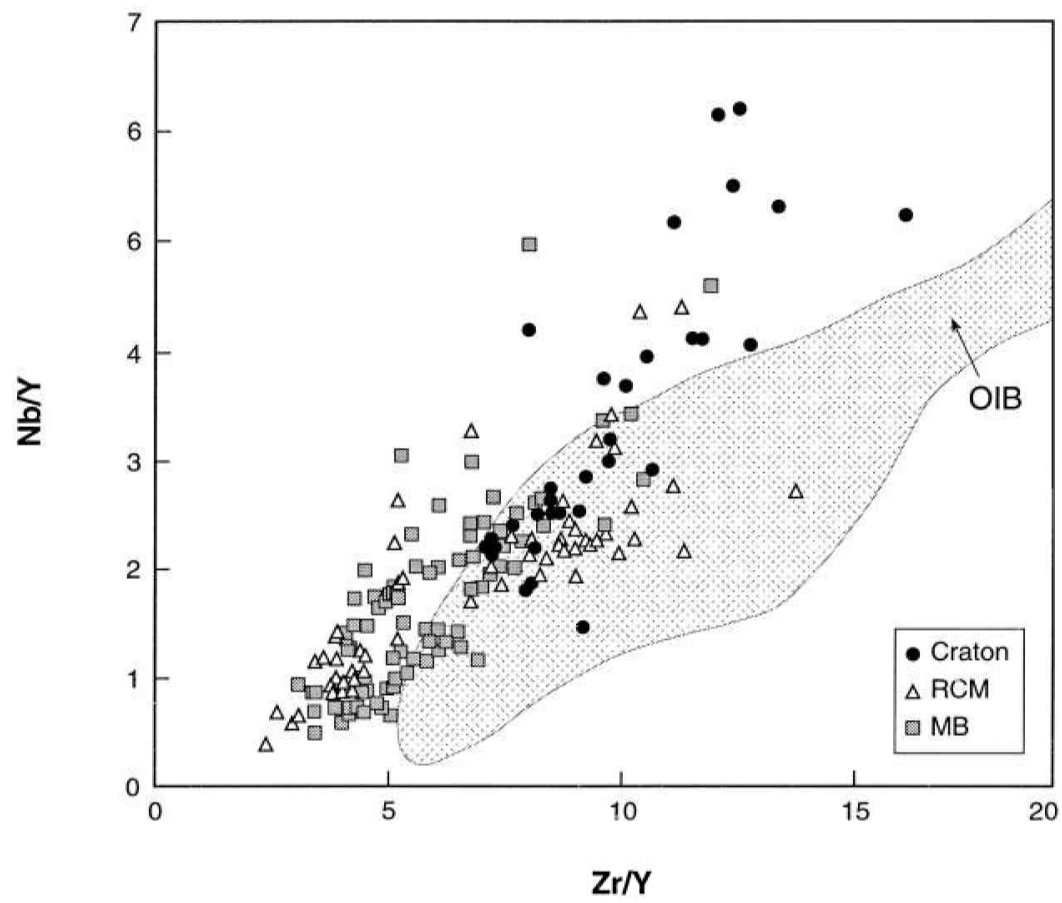

Figure $7 \mathrm{Zr} / \mathrm{Y}-\mathrm{Nb} / \mathrm{Y}$ plot to show that many mafic rocks of the axial regions of the Kenya rift are depleted in $\mathrm{Zr}$ relative to $\mathrm{Nb}$ compared to OIB (Macdonald et al. 2001, fig. 12). 
ocean island basalts (OIB). This is exemplified in a $\mathrm{Nb} / \mathrm{Y}-\mathrm{Zr} / \mathrm{Y}$ plot (Fig. 7); several rocks from each lithospheric domain have high values of $\mathrm{Nb} / \mathrm{Y}$ at a given $\mathrm{Zr} / \mathrm{Y}$ compared to OIB. The trace element data are consistent with isotopic evidence against a simple OIB-like source for the rift magmas (Paslick et al. 1995; Kalt et al. 1997). However, the large degree of overlap between the Kenya and OIB compositions (e.g. Fig. 7) indicates some common source and/or process and several recent geochemical studies have concluded that the Kenyan mafic magmas have resulted from the interaction of a plume component similar to the source of OIB, and a strongly heterogeneous lithospheric component (Class et al. 1994; Paslick et al. 1995; Späth et al. 2000, 2001; Kabeto et al. 2001a; Le Roex et al. 2001; Macdonald et al. 2001).

There is considerable compositional variation within the magma types, resulting from substantial decoupling of the incompatible trace elements (including $\mathrm{K}$, Ti and $\mathrm{P}$ ), reflected, for example, in the ranges of ratios (Fig. 7) and in different mantle-normalised patterns, even for rocks of the same magma type from the same successions (Fig. 8). The variability in incompatible trace element ratios occurs in rocks ranging from nephelinitic to hypersthene-normative basalt in each lithospheric domain, and in rocks with $m g$-number ranging from 40 to 80 . Macdonald et al. (2001) concluded that much of the variability must be mantle derived and envisaged one or more of the mantle sources as being strongly heterogeneous on a local scale. Since compositional heterogeneities are unlikely to persist in convecting mantle, they inferred that the highly variable component was metasomatised lithosphere.

$\mathrm{The} \mathrm{Sr}$ and $\mathrm{Nd}$ isotope systematics of lavas from the rift valley provide evidence that the compositional heterogeneity is at least partly related to one or more chemical fractionations (depletions) in the Proterozoic, and a series of metasomatic events, one of which undoubtedly occurred shortly before and during the Cenozoic activity, others of which may be the result of subduction, accretion and magmatic events related to Archaean, Proterozoic and Panafrican orogenies (Norry et al. 1980; Cohen et al. 1984; Davies \& Macdonald 1987; Rehkämper et al. 1997;
Dawson \& Smith 1988; Rudnick et al. 1993; Chesley et al. 1999; Burton et al. 2000; Späth et al. 2000).

The Cenozoic enrichment process(es) probably involved modal metasomatism, where metasomatic melts or fluids, possibly plume-derived, infiltrated and pervasively modified the subcontinental lithospheric mantle (SCLM), precipitating minerals such as amphibole and apatite (Bedini et al. 1997; Späth et al. 2000, 2001; Macdonald et al. 2001). The infiltration generated a melt accumulation zone at the transition between adiabatic and conductive mantle, i.e. at the base of the lithosphere. With melt-rock reactions at increasing melt mass, this zone represents a potential source of magmas with a lithospheric geochemical signature. As a consequence of the continued rise of the plume, the regional geotherm was raised, leading to generation of the rift magmas.

The concept of plume-lithosphere interaction is attractive for the Kenya rift because, by assuming that the degree of infiltration by plume melts and of melt-rock reactions was highly variable over short distances, it can generate significant variation in incompatible trace element abundances in closely related rocks. Furthermore, locating the interaction zone close to the base of the SCLM would decrease the involvement of the overlying lithosphere, producing primitive magmas with similar compositional characteristics being emplaced through a range of basement types (Macdonald et al. 2001).

It is possible that carbonatites in the rift system, which are largely restricted to areas of exposed Archaean rocks (Le Bas 1987; Smith 1994), were generated entirely within the lithosphere. Kalt et al. (1997) noted that the carbonatite complexes in the EARS have been derived from small, isotopically distinct mantle sources which cannot be described in terms of the mantle components defined for OIB (and thus the inferred Kenya plume(s)). They suggested that the carbonatites were formed by partial melting of carbonated phlogopite and/or amphibolebearing peridotites in heterogeneous lithospheric mantle affected by enrichment and depletion processes at different times.

An alternative view is that the $\mathrm{Nd}-\mathrm{Sr}-\mathrm{Pb}$ isotope geochemistry of the Kenyan carbonatites reveals mixing in a plume

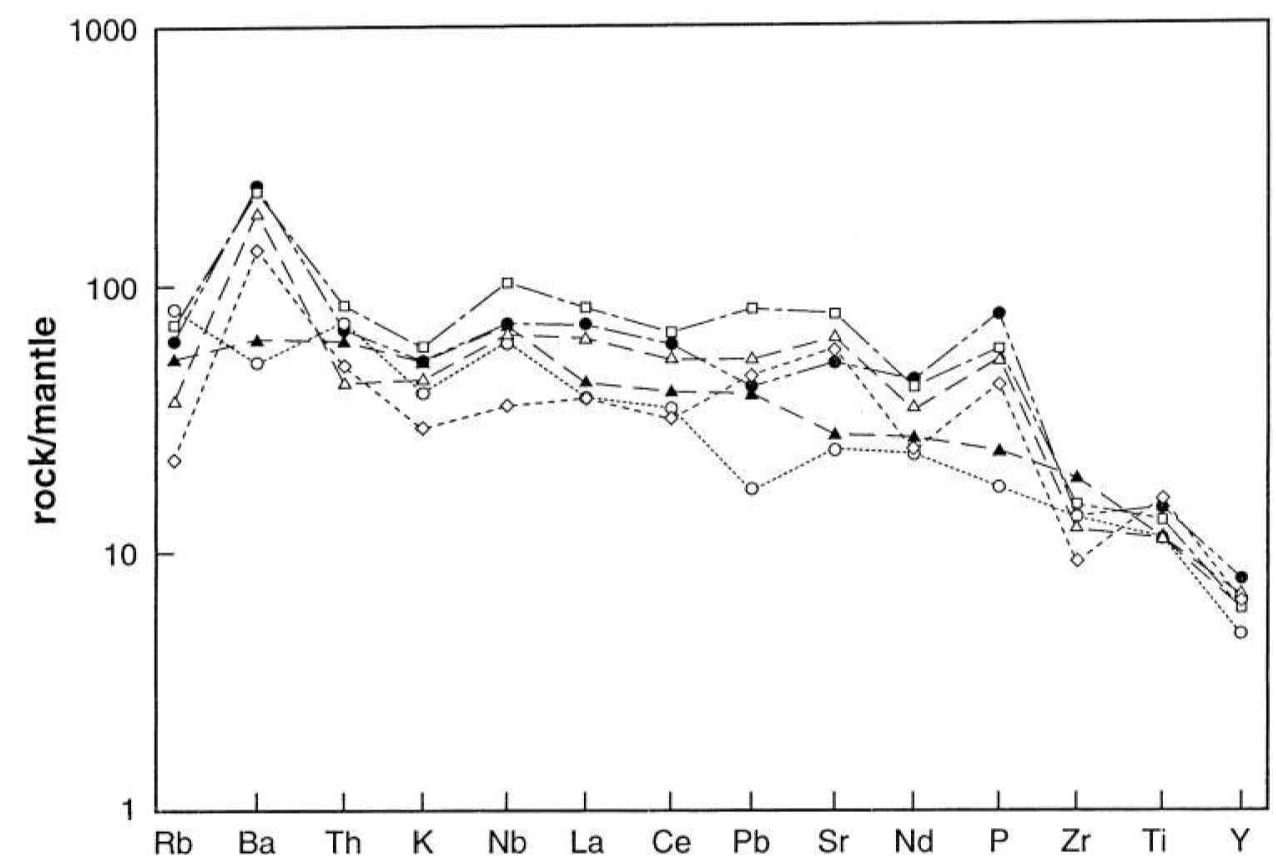

Figure 8 Mantle-normalised plots for five, selected, Pliocene alkali olivine basalts from a geographically restricted area just $\mathrm{N}$ of Lake Baringo (Fig. 4). Notice the variability in the patterns, even in rocks from the same Formation $(\Delta, \bullet, \circ$; Nasorut Basalt Formation). Normalising data from Sun \& McDonough (1989). From Macdonald et al. (2001, fig. 15). 
between two components of deep (lower $1000 \mathrm{~km}$ ) mantle origin (Bell \& Tilton 2001). The role of the subcontinental lithosphere is then to concentrate volatiles at the upper levels of the ascending plume.

\section{Plume component and number of plumes}

There is strong geophysical and geochemical evidence for the involvement of a mantle plume (the Afar plume) in the generation of the Ethiopian flood basalts and the magmatism in Afar (Marty et al. 1996; Hoffman et al. 1997). There is, however, no consensus as to the number of plumes influencing the tectonomagmatic development of the Kenya rift, current estimates ranging from none (Bailey 1992; King \& Ritsema 2000), through one (though not necessarily the same one; Ebinger \& Sleep 1998; Birt et al. 1997; Mechie et al. 1997), two (Ebinger et al. 1989; George et al. 1998; Rogers et al. 2000), to three (Burke 1996).

The source of the inferred plumes is being explored using seismic techniques, particularly seismic tomography. LithgowBertelloni \& Silver (1998), Ritsema et al. (1999), Helmberger et al. (2000), Zhao (2001) and Ni et al. (2002) have all imaged a very large, low-velocity structure $(>1000 \mathrm{~km}$; the so-called African Superplume) extending obliquely from the core-mantle boundary beneath southern Africa into the uppermost mantle beneath the EARS. Ni et al. (2002) suggest that the boundary of this anomaly is sharp, $<50 \mathrm{~km}$ wide. It is uncertain whether the structure is thermal, chemical, or both, in origin.

In contrast, Nyblade et al.'s (2000) preferred interpretation of variations in upper mantle seismic velocity beneath northern Tanzania is that they can be attributed to a mantle plume whose head is present under the keel of the Tanzanian craton. They present evidence that there is a wide (several hundreds of kilometres) depression of the $410 \mathrm{~km}$ seismic discontinuity but not the $660 \mathrm{~km}$ discontinuity, suggesting that the tail of the plume lies within the upper mantle. They envisage a lateral flow of plume material along the eastern edge of the craton, generating lithospheric uplift across the East African Plateau. Decompression melting of hot plume material gives rise to the magmatism of the EARS.

The strong lithospheric geochemical signature imposed on Kenyan magmas makes identification of the plume component required by the eruptive volumes very difficult. However, the craton and mobile belt data have a common end-member at ${ }^{143} \mathrm{Nd} /{ }^{144} \mathrm{Nd} \sim 0.51275$ and ${ }^{87} \mathrm{Sr} /{ }^{86} \mathrm{Sr} \sim 0.7035$ (Rogers et al. 2000; Macdonald et al. 2001), this composition lying within the range of OIB (Hofmann 1997). Furthermore, the majority of rift mantle-normalised incompatible trace element patterns are broadly similar to OIB (Fig. 8) and it seems likely, therefore, that any plume component had OIB-like characteristics. The extent of lithosphere interaction apparently has not varied systematically in space or time, i.e. there has been no significant change towards an increased mantle plume, or any other, component (Macdonald et al. 2001). If the southwards initiation of magmatism in the Kenya rift has been caused by the passage of the African plate over a plume or by plume migration, then the chemical signature of the plume has been overprinted by interaction with lithospheric mantle.

Chesley et al. (1999) have identified possible plume material among ultramafic xenoliths from the Labait volcano, which lies on the eastern boundary of the Tanzanian craton. They use $\mathrm{Re}-\mathrm{Os}$ systematics of the xenoliths to propose that the lithosphere to depths of $\sim 140 \mathrm{~km}$ is refractory harzburgite which, on the basis of Re depletion ages, was stabilised between 2.5 and $2.9 \mathrm{Ga}$. Between $\sim 140 \mathrm{~km}$ and $150 \mathrm{~km}$ depth, the peridotites are garnet-bearing, more fertile, deformed and have more radiogenic Os than the overlying lithosphere. These peridotites may represent mixtures of ancient lithosphere and underlying plume or younger $(\leq 1 \mathrm{Ga})$ additions to the base of the lithosphere. One xenolith sample has the major element composition of primitive mantle and the radiogenic ${ }^{187} \mathrm{Os} /{ }^{188} \mathrm{Os}$ ratio characteristic of plume-derived oceanic basalts.

Rogers et al. (2000) used $\mathrm{Nd}$ and $\mathrm{He}$ isotopic evidence to suggest that any Kenyan plume component is distinct from the Afar plume further $\mathrm{N}$, inferring that at least two sublithospheric upper mantle source regions contribute to the mafic rocks of the EARS within a length scale of $2000 \mathrm{~km}$.

\section{Polybaric fractionation}

Whilst locally common, e.g. in the Huri Hills (Class et al. 1994) and Chyulu Hills (Späth et al. 2000, 2001), rocks representing possible primary magmas $(m g$-number $>65)$ are normally relatively scarce in the Kenya rift (Macdonald 1994; Macdonald et al. 2001). The overwhelming majority of basalts have compositions consistent with substantial polybaric fractionation of olivine-dominated assemblages from primary magmas. Karson \& Curtis (1989) pointed out the requirement that the emplacement of huge volumes of magma in the rift has been accompanied by the formation of at least three to four times as much mafic and ultramafic cumulates. The fact that the greatest volumes of basalts in the rift straddle the critical plane of silica-saturation (which becomes operative at $\sim 24 \mathrm{~km}$ depth) indicates that a considerable proportion of the cumulates must have formed at, or close to, the crust-mantle boundary, maintaining crustal thickness by underplating.

The further fractionation histories of the mafic magmas probably depended on local tectonics. Some magma batches retained around the crust-mantle boundary may have evolved by extended fractionation involving separation of olivine \pm clinopyroxene \pm plagioclase, through hawaiitic to benmoreitic compositions before their densities were lowered sufficiently for them to ascend higher into the crust. Other basaltic magma batches ascended high into the crust; for example, gravity highs under the trachytic caldera volcanoes Suswa and Menegai (Fig. 4) have been interpreted by Swain (1992) as mafic intrusions.

Petrogenetic modelling has revealed that the compositional variations in many basalt-trachyte suites are consistent with fractional crystallisation of basaltic parental magmas. Generally, the degree of silica-saturation of the basaltic parents is reflected in that of the daughter magmas; mildly alkaline basalts are associated with trachytes which are mildly nepheline- or quartz-normative; nephelinitic and basanitic magmas generated phonolitic residua (Sceal \& Weaver 1971; Baker et al. 1977; Weaver 1977; Brotzu et al. 1983; Price et al. 1985; Baker 1987; Macdonald et al. 1995; Kabeto et al. 2001a,b). Isotopic data, where available, indicate that fractional crystallisation was commonly accompanied by usually minor assimilation of crustal rocks (Norry et al. 1980; Davies \& Macdonald 1987; Macdonald et al. 1995; Kabeto et al. 2001a,b).

Dolerite blocks, containing residual glasses varying from mugearitic to peralkaline phonolitic compositions and thought to have been disrupted from a high-level, sill-like intrusion under the Silali basalt-trachyte caldera volcano (see Fig. 4), provide an analogue of the low-pressure fractionation of alkali olivine basaltic magma (Macdonald et al. 1995). Low-pressure 
fractionation of $h y$-normative basalts at Silali is believed to have generated quartz trachytes.

In some Quaternary volcanoes, extreme fractionation of trachytic magma has generated compositionally zoned ash flow tuffs, e.g. Menengai (Leat et al. 1984; Macdonald et al. 1994a), Longonot (Clarke et al. 1990) and Suswa (Macdonald et al. 1993). At a late stage of the fractionation of the Suswa magma, a carbonatitic melt separated immiscibly, reinforcing views that $\mathrm{CO}_{2}$ has played an important role in the petrogenesis of the salic rocks of the Kenya rift (Bailey 1978, 1980, 1987; Scott 1982).
Geophysical data (Swain 1992) are consistent with the view that each of the central volcanoes of the rift axis (Fig. 4) represents a nexus, where the regional dyke swarm has fed high-level reservoirs. There is the potential, in such systems, for magma to flow into the reservoirs vertically and laterally. Thus, major vent alignments at the Longonot and Suswa caldera volcanoes (Fig. 4) are parallel to regional fault trends, whilst the volume of material consumed during caldera formation at each centre is markedly greater than magma volumes erupted during syn-caldera activity (Scott \& Skilling 1999). An episode of regional extension in the southern rift

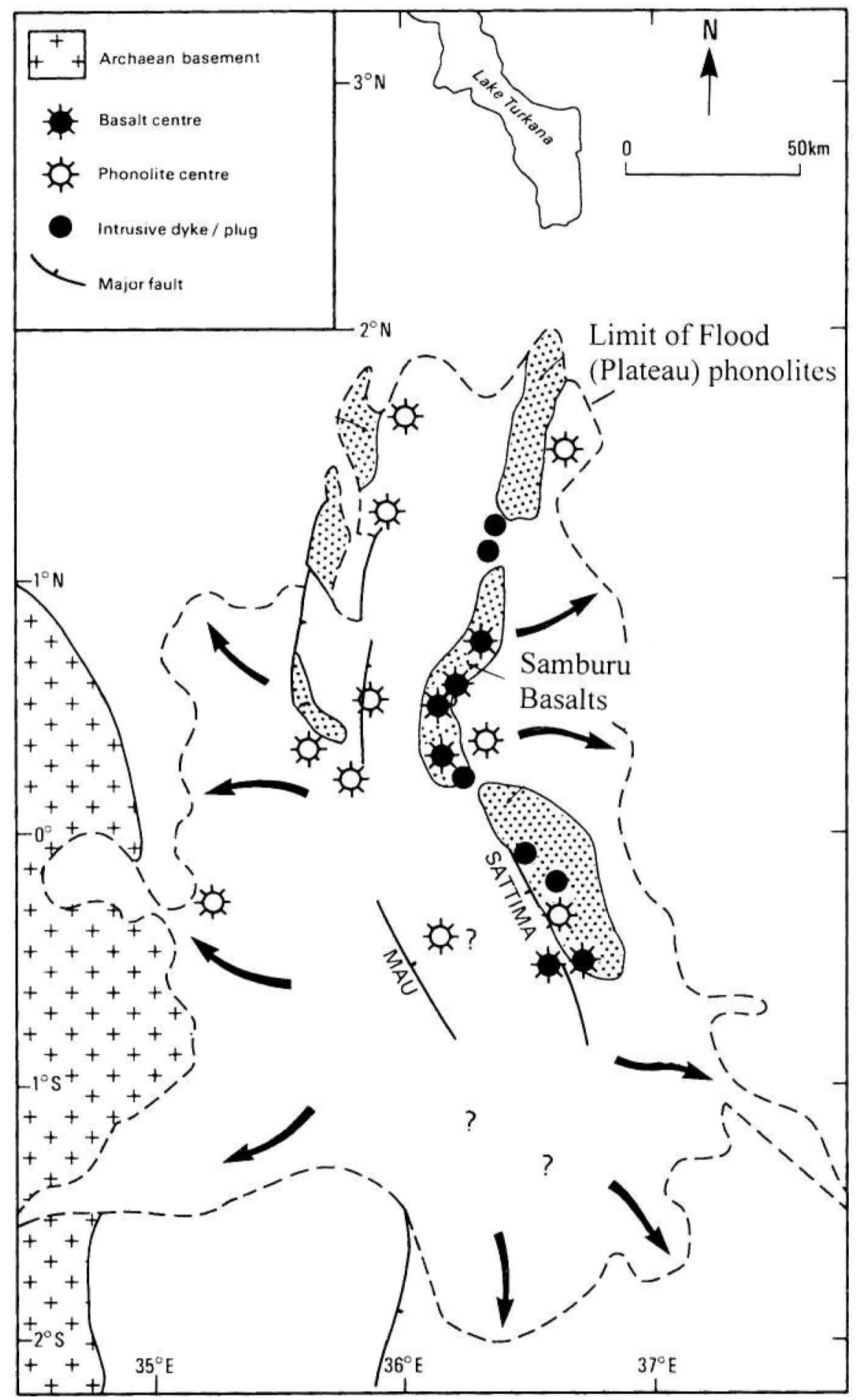

Figure 9 Approximate distribution of the Miocene Flood (Plateau) Phonolites (from Smith 1994, fig. 2). Also shown (stippled fields) are outcrops of the Samburu Basalts (20-11 Ma) and contemporaneous basalt formations, and known and inferred eruptive centres of phonolites and basalts. The loci of eruptive centres broadly coincide with the axis of the Kenya Dome. 
may have triggered synchronous lateral magma withdrawal along regional fractures, decompression of the magma chambers and caldera collapse. A small amount of mixing of Suswa trachyte magma with peralkaline rhyolite magma of the Olkaria centre (Fig. 4) was facilitated by the lateral propagation of comendite magma southwards along a N-S tension fracture which links the two centres (Scott \& Skilling 1999). Further N, at the Emuruangogolak caldera volcano (Fig. 4), Black et al. (1998) used trace element and isotopic evidence to show that young $(<38 \mathrm{ka})$ basalts, comenditic trachytes and pantelleritic trachytes represent several magmatic lineages, sometimes erupted as part of the same stratigraphic group. They suggested that the Emuruangogolak plumbing system is remarkably open and is fed by multiple dyke injection close to the surface.

A petrological highlight of the Kenya rift is undoubtedly the active carbonatite volcano Oldoinyo Lengai, Tanzania. Whilst perhaps best known for the eruption of natrocarbonatite lavas and pyroclastics, the volcano is dominated by silicate lavas. Dawson (1998) has used young $(<2000$ years $)$ nephelinites associated with the natrocarbonatite to examine the petrogenetic relationships between the silicate and carbonate phases. There are two types of nephelinites: combeite nephelinites and wollastonite nephelinites, the natrocarbonatite being associated with the latter. Dawson (1998) proposed that the genetic link is fractionation of a parental carbonated olivine nephe- linite magma under conditions of carbonate saturation, permitting unmixing of carbonate.

\section{Partial melting of deep crust}

A notable feature of the magmatism of the Kenya rift is the huge volumes of salic rocks which have been generated at various times. For example, the eruption of the sequences comprising the Plateau Phonolites represents the largest phase of extrusive volcanism in the rift (Fig. 9). Eruptions continued from 16 to 8 $\mathrm{Ma}$, with the major part erupted between 13 and $11 \mathrm{Ma}$. The volume of the Plateau Phonolites has been estimated to be between 25,000 and 50,000 $\mathrm{km}^{3}$ (Williams 1972; Lippard 1973). In late Pliocene times, volcanism of the central sector of the rift valley was dominated by the emplacement of thick (up to $300 \mathrm{~m}$ ) welded and non-welded tuffs and ashfall deposits, of trachytic and phonolitic composition (Fig. 10). Total aggregate volumes are of the order of $6000-7000 \mathrm{~km}^{3}$, possibly as high as $10,000 \mathrm{~km}^{3}$ (Smith 1994).

Bailey $(1964,1974)$ considered that these volumes were too great to have formed by fractional crystallisation of basaltic magma, and proposed instead that they were the products of partial melting of crystalline parent materials, such as alkali basalt, in the lower crust, the main mechanisms being relief of pressure attendant upon upwarping of the lithosphere and

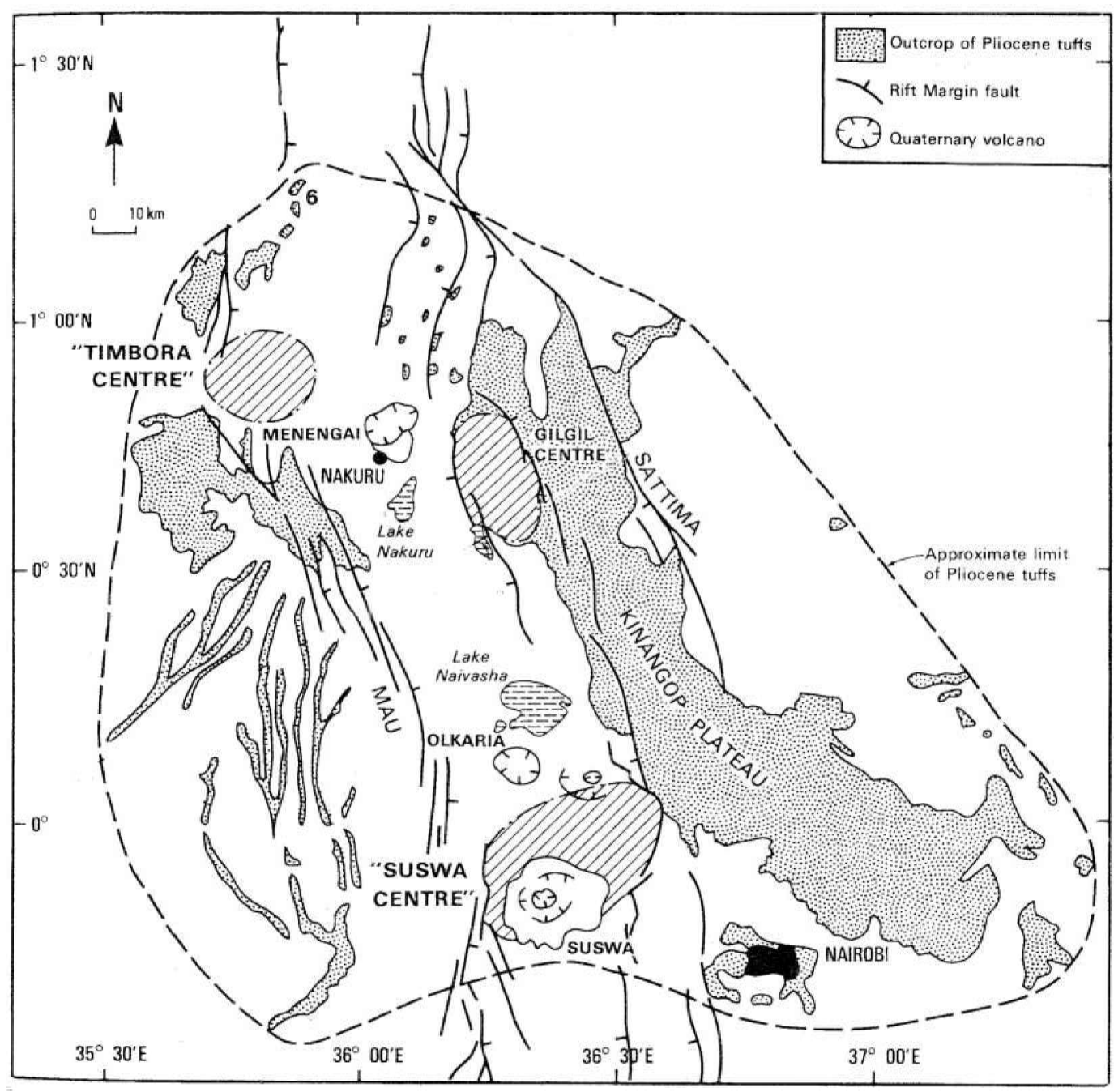

Figure 10 Outcrop pattern and approximate limit of Pliocene trachyte/phonolite tuffs (modified from Smith 1994, fig. 3). Various centres, inferred mainly from analysis of lateral facies and thickness variations, are also shown (hachured areas), as are some Quaternary volcanoes. 
addition of volatiles from the underlying mantle. The relevant crustal layer may be the high-velocity seismic layer $(6 \cdot 8-7 \cdot 1$ $\mathrm{km} \mathrm{s}^{-1}$ ) identified at $25-35 \mathrm{~km}$ depth, i.e. at the base of the crust beneath the central rift, which has been interpreted as a mix of high-grade metamorphic rocks and underplating mafic and ultramafic material (Mooney \& Christensen 1994; Hay et al. 1995a,b; Mechie et al. 1997).

The partial melting hypothesis was given significant support by the experimental studies of Hay \& Wendlandt (1995), who determined the near-liquidus melting relations of a relatively mafic, plateau-type phonolite from the Kenya rift. They found multiple saturation of andesine, augite, phlogopite, apatite and oxides at $0.7 \mathrm{GPa}, 1000^{\circ} \mathrm{C}$, and $X_{\mathrm{CO}_{2}} \supset 0.42$, with amphibole appearing at $975^{\circ} \mathrm{C}$. The assemblage and the compositions of the phases were interpreted to indicate that plateau phonolite liquids were derived by some $15 \%$ equilibrium melting of rocks of alkali basalt composition in the lower crust $(\sim 23 \mathrm{~km})$. Hay \& Wendlandt (1995) suggested that these liquids ascended fairly rapidly, degassing $\mathrm{CO}_{2}$, to high-level reservoirs, where low-pressure phenocryst assemblages formed. Hay et al. (1995a,b) showed that geochemical, especially isotopic, data for plateau phonolites are consistent with mantle-derived parental compositions.
The mafic crustal rocks thought to be parental to the phonolites may have been added to the $6.8 \mathrm{~km} \mathrm{~s}^{-1}$ basal layer during an extensive phase of alkali basaltic magmatism which occurred early in the evolution of the rift (23-14 Ma; Hay et al. 1995b). The addition of significant magma volumes may also have played a role in the uplift of the Kenya Dome, around which the phonolites (and Pliocene tuffs) are centred (Figs 9, 10; Smith 1994).

Kaszuba \& Wendlandt (2000) examined the role of $\mathrm{CO}_{2}$ in Kenyan magmatism via dehydration melting experiments on alkali basalt. Experiments were performed at $0.7 \mathrm{GPa}$ and $1 \mathrm{GPa}, 850-1100^{\circ} \mathrm{C}, 3-5 \mathrm{wt} \% \mathrm{H}_{2} \mathrm{O}$, and near the $\mathrm{NNO}$ buffer. Variable amounts of $\mathrm{CO}_{2}$ (molar $\mathrm{CO}_{2} / \mathrm{H}_{2} \mathrm{O} \quad \mathrm{CO}_{2} \supset 0 \cdot 2$ $0.9)$ were added to experiments at $1025^{\circ} \mathrm{C}$ and $1050^{\circ} \mathrm{C}$. Dehydration melting in the hydrous system produced silicaoversaturated, peraluminous melts, whereas with $\mathrm{CO}_{2}$ present, nepheline-normative tephriphonolite, trachyandesite and trachyte melts were generated. Kaszuba \& Wendlandt (2000) use their results to predict that many suites of continental alkaline rocks, such as those of the Kenya rift, are derived by lowpressure dehydration melting of alkali basalt-carbon dioxide crustal systems. (a)

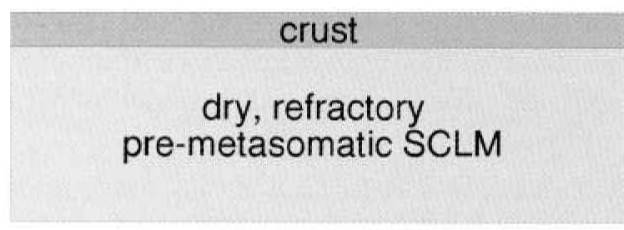

(b)

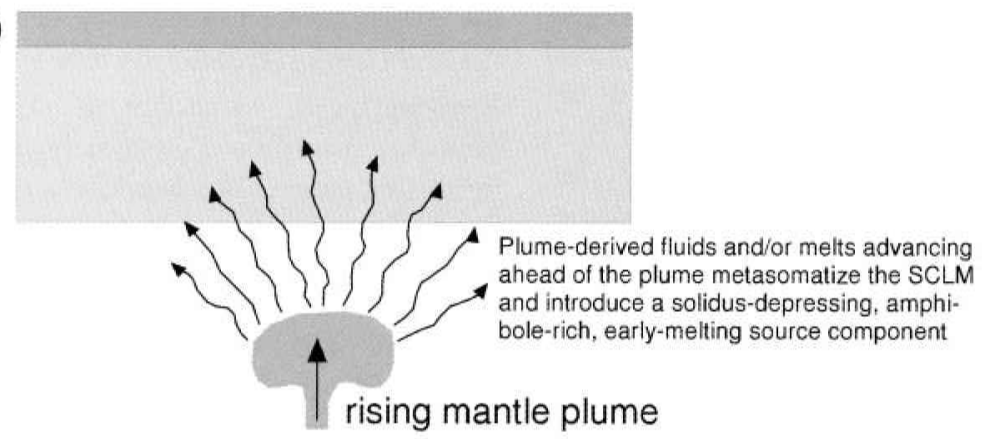

(c)

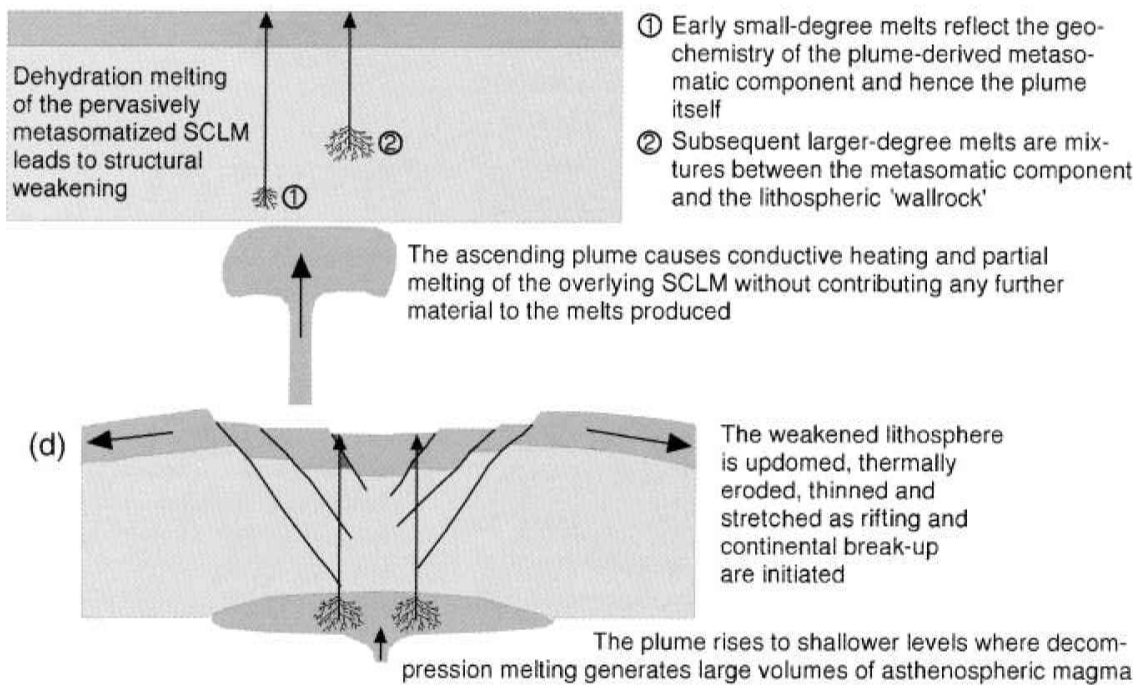

Figure 11 Schematic illustration of the Cenozoic evolution of the Kenya rift, based on the interaction of an ascending mantle plume with initially dry, (partially) depleted lithospheric mantle. This model, constructed by Späth et al. (2001) for the Chyulu Hills Volcanic Province on the southeastern rift flanks, is here considered to be generally applicable to the whole rift. No part of the Kenya rift has reached the 'continental break-up' phase represented in stage d. Reproduced with permission of Oxford University Press. 


\section{High-level partial melting of crust}

High-silica rhyolites are not common in the Kenya rift. The only late Quaternary occurrences are at Olkaria and Eburru, which lie on the crest of the Kenya Dome near Lake Naivasha (Fig. 4). There are at least 80 small volcanic centres in the Olkaria field, overwhelmingly of mildly peralkaline (comenditic) composition. Basalt lavas occur peripherally to the field and as components of mixed magma rocks and it is likely that basaltic magma underlies the whole field. The field shows unusually high heat flow, temperatures as high as $280^{\circ} \mathrm{C}$ having been recorded at depths of $1350 \mathrm{~m}$ (Noble \& Ojiambo 1975), suggesting that basalt magma has penetrated to high levels.

There is strong geochemical evidence, particularly from $\mathrm{Pb}$ isotopes (Davies \& Macdonald 1987) and U-series disequilibria and Th isotopes (Black et al. 1997; Heumann \& Davies 2002), that the Olkaria rhyolites were formed by partial melting of high-level crustal rocks. Experimental work by Scaillet \& Macdonald (2001) has outlined the likely preeruptive conditions for the rhyolites; last equilibration was at an oxygen fugacity at, or possibly below, FMQ, temperatures between $740^{\circ} \mathrm{C}$ and $660^{\circ} \mathrm{C}$ and pressures $\leq 150 \mathrm{MPa}$, equivalent to $\sim 5 \mathrm{~km}$ depth. Melt evolution occurred under near $\mathrm{H}_{2} \mathrm{O}$ saturation conditions, with pre-eruptive melt water contents as high as $6 \mathrm{wt} \%$.

\section{General significance of the Cenozoic magmatism}

The main features of the Cenozoic magmatic history of the Kenya rift are now summarised, using as a basis the evolutionary cartoon of Späth et al. (2001), which although envisaged for generation of the Chyulu lavas, can be used as a model for magmatism over the whole Kenya rift (Fig. 11).

In Pre-Miocene times, one or more plumes, of uncertain source, rose high into the asthenosphere beneath the SCLM, at least parts of which had been chemically depleted and reenriched during previous magmatic events (Fig. 11a). The SCLM was metasomatised by melts and/or fluids released from the ascending plume(s) (Fig. 11b). When the plume material reached depths of $\leq 150 \mathrm{~km}$, dynamic uplift at the surface initiated formation of the Kenya Dome.

By Miocene times, continued uprise of the plume raised geothermal gradients and permitted dehydration melting of the metasomatised lithospheric mantle. Partial melting occurred across the garnet-spinel transition and degrees of melting were small, generally $<3 \%$. Primary magmas ranged in composition from nephelinitic to $h y$-normative basaltic, more silicaundersaturated varieties being generated at greater depths (Fig. 11c). The primary magmas underwent variable polybaric fractionation histories, which included important contributions to a high-velocity basal crustal layer. This layer may have acted, via volatile-fluxed partial melting, as the source for flood phonolites and trachytes. Trachytic and phonolitic magmas were also formed by crystal fractionation of basaltic magma in mid-crustal and high-level magma chambers. Locally, intrusion of basalt high into the crust resulted in volatile-fluxed partial melting of crustal protoliths to produce peralkaline, high-silica rhyolites.

With reference to continental flood basalt provinces, Gallagher \& Hawkesworth (1992) and Turner et al. (1996) have argued that early melt generation within hydrated lithosphere (for a $\sim 100 \mathrm{~km}$-thick mechanical boundary layer) within the first few million years of conductive heating by a plume will be followed by a greater asthenospheric contribu- tion, once the $\beta$-factor reaches a value $>2$. Calling on the Turner et al. (1996) model, Le Roex et al. (2001) suggest that at least the southern part of the Kenya rift is analogous to the early stages of a major flood basalt province, with melting taking place entirely within the lithosphere and the amounts of extension being low. One implication of the plume model might be that, at some future stage, Kenyan magmatism will show an increasing plume signature, and the plume will eventually lead to continental break-up (Fig. 11d). Whether a plume alone can drive continental break-up, or would require the cooperation of favourable far-field tectonic stresses, is for the moment far from clear.

\section{Acknowledgements}

I am very grateful to Barry Dawson and Nick Rogers for incisive reviews that helped keep me honest.

\section{References}

Achauer, U. \& KRISP Teleseismic Working Group 1994. New ideas on the Kenya rift based on the inversion of the combined dataset of the 1985 and 1989/90 seismic tomography experiments. Tectonophysics 236, 305-29.

Bailey, D. K. 1964. Crustal warping - a possible tectonic control of alkaline magmatism. Journal of Geophysical Research 69, 1103-11.

Bailey, D. K. 1974. Melting in the deep crust. In Sørensen, H. (ed.) The Alkaline Rocks, 436-42. London: Wiley.

Bailey, D. K. 1978. Continental rifting and mantle degassing. In Neumann, E. R. \& Ramberg, I. B. (eds) Petrology and Geochemistry of Continental Rifts, 1-13. Dordrecht: Reidel.

Bailey, D. K. 1980. Volcanism, earth degassing and replenished mantle lithosphere. Philosophical Transactions of the Royal Society of London A297, 309-22.

Bailey, D. K. 1987. Mantle metasomatism - perspective and prospect. In Fitton, J. G. \& Upton, B. G. J. (eds) Alkaline Igneous Rocks, Geological Society, London, Special Publication 30, 1-13. London: Geological Society.

Bailey, D. K. 1992. Episodic alkaline igneous activity across Africaimplications for the causes of continental break-up. In Storey, B. C., Alabaster, T. \& Pankhurst, R. J. (eds) Magmatism and the Causes of Continental Break-up, Geological Society, London, Special Publication 68, 91-8. London: Geological Society.

Baker, B. H. 1987. Outline of the petrology of the Kenya rift alkaline province. In Fitton, J. G. \& Upton, B. G. J. (eds) Alkaline Igneous Rocks, Geological Society, London, Special Publication 27, 293 311. London: Geological Society.

Baker, B. H., Goles, G. G., Leeman, W. P. \& Lindstrom, M. M. 1977. Geochemistry and petrogenesis of a basalt-benmoreite-trachyte suite from the southern part of the Gregory Rift, Kenya. Contributions to Mineralogy and Petrology 64, 303-32.

Bedini, R. M., Bodinier, J.-L., Dautria, J.-M. \& Morten, L. 1997. Evolution of LILE-enriched small melt fractions in the lithospheric mantle: a case study from the East African Rift. Earth and Planetary Science Letters 153, 67-83.

Bell, K. \& Tilton, G. R. 2001. Nd, Pb and Sr isotopic compositions of East African carbonatites: evidence for mantle mixing and plume inhomogeneity. Journal of Petrology 42, 1927-45.

Birt, C. S., Maguire, P. K. H., Khan, M. A., Thybo, H., Keller, G. R. \& Patel, J. 1997. The influence of pre-existing structures on the evolution of the southern Kenya Rift Valley-evidence from seismic and gravity studies. Tectonophysics $\mathbf{2 7 8}, 211-42$.

Black, S., Macdonald, R. \& Kelly, M. R. 1997. Crustal origin for peralkaline rhyolites from Kenya: evidence from U-series disequilibria and Th-isotopes. Journal of Petrology 38, 277-97.

Black, S., Macdonald, R., Barreiro, B. A., Dunkley, P. N. \& Smith, M. 1998. Open system alkaline magmatism in northern Kenya: evidence from U-series disequilibria and radiogenic isotopes. Contributions to Mineralogy and Petrology 131, 364-78.

Brotzu, P., Morbidelli, L., Piccirillo, E. M. \& Traversa, G. 1983. The basanite to peralkaline phonolite suite of the plioquaternary Nyambeni multicentre volcanic range (East Kenya Plateau). Neues Jahrbuch für Mineralogie Abh. 147, 253-80. 
Burke, K. 1996. The African Plate. South African Journal of Geology 99, 341-409.

Burton, K. W., Schiano, P., Birck, J.-L., Allègre, C. J., Rehkämper, M., Halliday, A. N. \& Dawson, J. B. 2000. The distribution and behaviour of rhenium and osmium amongst mantle minerals and the age of the lithospheric mantle beneath Tanzania. Earth and Planetary Science Letters 183, 93-106.

Chesley, J. T., Rudnick, R. L. \& Lee, C.-T. 1999. Re-Os systematics of mantle xenoliths from the East African Rift: Age, structure and history of the Tanzanian craton. Geochimica et Cosmochimica Acta 63, 1203-17.

Clarke, M. C. G., Woodhall, D. G., Allen, D. \& Darling, G. 1990. Geological, volcanological and hydrogeological controls on the occurrence of geothermal activity in the area surrounding Lake Naivasha, Kenya. Report. Nairobi: Ministry of Energy.

Class, C., Altherr, R., Volker, F., Eberz, G. \& McCulloch, M. T. 1994. Geochemistry of Pliocene to Quaternary alkali basalts from the Huri Hills, northern Kenya. Chemical Geology 113, 1-22.

Cohen, R. S., O’Nions, R. K. \& Dawson, J. B. 1984. Isotope geochemistry of xenoliths from East Africa: implications for development of mantle reservoirs and their interaction. Earth and Planetary Science Letters 68, 209-20.

Davies, G. R. \& Macdonald, R. 1987. Crustal influences in the petrogenesis of the Naivasha basalt-comendite complex: combined trace element and $\mathrm{Sr}-\mathrm{Nd}-\mathrm{Pb}$ constraints. Journal of Petrology 28, 1009-31.

Dawson, J. B. 1998. Peralkaline nephelinite-natrocarbonatite relationships at Oldoinyo Lengai, Tanzania. Journal of Petrology 39, 2077-94

Dawson, J. B. \& Smith, J. V. 1973. Alkalic pyroxenite xenoliths from the Lashaine volcano, northern Tanzania. Journal of Petrology 14, $113-31$

Dawson, J. B. \& Smith, J. V. 1988. Metasomatised and veined uppermantle xenoliths from Pello Hill, Tanzania: evidence for anomalously-light mantle beneath the Tanzanian sector of the East African Rift Valley. Contributions to Mineralogy and Petrology 100, 510-27.

Ebinger, C. J., Bechtel, T., Forsyth, D. \& Bowin, C. 1989. Effective elastic plate thickness beneath the east African and Afar plateaus and dynamic compensation for the uplifts. Journal of Geophysical Research 94, 2883-901.

Ebinger, C., Djomani, Y. P., Mbede, E., Foster, A. \& Dawson, J. B. 1997. Rifting Archaean lithosphere: the Eyasi-Manyara-Natron rifts, East Africa. Journal of the Geological Society, London 154, 947-60.

Ebinger, C. J., Yemane, T., Harding, D. J., Tesfaye, S., Kelley, S. \& Rex, D. C. 2000. Rift deflection, migration, and propagation: Linkage of the Ethiopian and Eastern Rifts, Africa. Bulletin of the Geological Society of America 112, 163-76.

Ebinger, C. J. \& Sleep, N. H. 1998. Cenozoic magmatism throughout east Africa resulting from impact of a single plume. Nature $\mathbf{3 9 5}$, 788-91.

Fuchs, K., Altherr, R., Müller, B. \& Prodehl, C. (eds) 1997. Structure and dynamic processes in the lithosphere of the Afro-Arabian Rift System. Tectonophysics $\mathbf{2 7 8}$.

Gallagher, K. \& Hawkesworth, C. J. 1992. Dehydration melting and the origin of continental flood basalts. Nature 358, 57-9.

George, R. M. M., Rogers, N. W. \& Kelley, S. 1998. Earliest magmatism in Ethiopia: evidence for two mantle plumes in one flood basalt province. Geology 26, 923-6.

Hardarson, B. S. \& Fitton, J. G. 1991. Increased mantle melting beneath Snaefellsjokull volcano during Late Pleistocene glaciation. Nature 353, 62-4.

Hay, D. E., Wendlandt, R. F. \& Wendlandt, E. D. 1995a. The origin of Kenya rift plateau-type flood phonolites: Evidence from geochemical studies for fusion of lower crust modified by alkali basaltic magmatism. Journal of Geophysical Research 100, 411-22.

Hay, D. E., Wendlandt, R. F. \& Keller, G. R. 1995b. The origin of Kenya rift plateau-type flood phonolites: Integrated petrologic and geophysical constraints on the evolution of the crust and upper mantle beneath the Kenya rift. Journal of Geophysical Research 100, 10549-57.

Hay, D. E. \& Wendlandt, R. F. 1995. The origin of Kenya rift plateautype flood phonolites: results of high-pressure/high-temperature experiments in the systems phonolite- $\mathrm{H}_{2} \mathrm{O}$ and phonolite- $\mathrm{H}_{2} \mathrm{O}$ $\mathrm{CO}_{2}$. Journal of Geophysical Research 100, 401-10.

Helmberger, D., Ni, S., Wen, L. \& Ritsema, J. 2000. Seismic evidence for ultralow velocity zones beneath Africa and eastern Atlantic. Journal of Geophysical Research 105, 23865-78.

Hendrie, D. B., Kusznir, N. J., Morley, C. K. \& Ebinger, C. J. 1994. Cenozoic extension in northern Kenya: a quantitative model of rift basin development in the Turkana region. Tectonophysics $\mathbf{2 3 6}$, 409-38.

Henjes-Kunst, F. \& Altherr, R. 1992. Metamorphic petrology of xenoliths from Kenya and northern Tanzania and implications for geotherms and lithospheric structure. Journal of Petrology 33, 1125-56.

Herzberg, C. 1995. Generation of plume magmas through time: an experimental perspective. Chemical Geology 126, 1-16.

Heumann, A. \& Davies, G. R. 2002. U-Th disequilibria and Rb-Sr age constraints on the magmatic evolution of peralkaline rhyolites from Kenya. Journal of Petrology 43, 557-77.

Hoffman, C., Courtillot, V., Féraud, G., Rochette, P., Yirgu, G., Ketefo, E. \& Pik, R. 1997. Timing of the Ethiopian flood basalt event and implications for plume birth and global change. Nature 389, $838-41$.

Hofmann, A. 1997. Mantle geochemistry: the message from oceanic volcanism. Nature 385, 219-29.

Ito, M. 1986. Kimberlites and their ultramafic xenoliths from western Kenya. Tschermaks Mineralogische und Petrographische Mitteilungen 35, 193-216.

Johnson, L. H., Jones, A. P., Church, A. A. \& Taylor, W. R. 1997. Ultramafic xenoliths and megacrysts from a melilitite tuff cone, Deeti, northern Tanzania. Journal of African Earth Sciences 25, $29-42$.

Kabeto, K., Sawada, Y., Iizumi, S. \& Wakatsuki, T. 2001a. Mantle sources and magma-crust interactions in volcanic rocks from the northern Kenya rift: geochemical evidence. Lithos 56, 111-39.

Kabeto, K., Sawada, Y. \& Wakatsuki, T. 2001b. Different evolution trends in alkaline evolved lavas from the northern Kenya Rift. Journal of African Earth Sciences 32, 419-33.

Kalt, A., Hegner, E. \& Satir, M. 1997. Nd, Sr, and $\mathrm{Pb}$ isotopic evidence for diverse lithospheric mantle sources of East African Rift carbonatites. Tectonophysics 278, 31-45.

Karson, J. A. \& Curtis, P. C. 1989. Tectonic and magmatic processes in the eastern branch of the East African Rift and implications for magmatically active continental rifts. Journal of African Earth Sciences 8, 431-53.

Kaszuba, J. P. \& Wendlandt, R. F. 2000. Effect of carbon dioxide on dehydration melting reactions and melt compositions in the lower crust and the origin of alkaline rocks. Journal of Petrology 41, 363-86.

Key, R. M., Rop, B. P. \& Rundle, C. C. 1987. The development of the Late Cenozoic alkali basaltic Marsabit Shield Volcano, northern Kenya. Journal of African Earth Sciences 6, 475-91.

King, S. D. \& Ritsema, J. 2000. African hot spot volcanism: smallscale convection in the upper mantle beneath cratons. Science $\mathbf{2 9 0}$, $1137-40$.

KRISP Working Party 1991. Large-scale variation in lithospheric structure along and across the Kenya rift. Nature 354, 223-7.

Latin, D., Norry, M. J. \& Tarzey, R. J. E. 1993. Magmatism in the Gregory Rift, East Africa: evidence for melt generation by a plume. Journal of Petrology 34, 1007-27.

Leat, P. T., Macdonald, R. \& Smith, R. L. 1984. Geochemical evolution of the Menengai caldera volcano, Kenya. Journal of Geophysical Research 89, 8571-92.

Le Bas, M. J. 1987. Carbonatite-Nephelinite Volcanism, An African Case History. London: Wiley.

Le Roex, A. P., Späth, A. \& Zartman, R. E. 2001. Lithospheric thickness beneath the southern Kenya Rift: implications from basalt geochemistry. Contributions to Mineralogy and Petrology 142, 89-106.

Lippard, S. J. 1973. Plateau phonolite lava flows, Kenya. Geological Magazine 110, 543-9.

Lippard, S. J. \& Truckle, P. H. 1978. Spatial and temporal variations in basalt geochemistry in the northern Kenya rift. In Neumann, R. \& Ramberg, I. B. (eds) Petrology and Geochemistry of Continental Rifts, 123-32. Dordrecht: Reidel.

Lithgow-Bertelloni, C. \& Silver, P. G. 1998 Dynamic topography, plate driving forces and the African superswell. Nature 395, 26972.

Macdonald, R. 1994. Petrological evidence regarding the evolution of the Kenya Rift Valley. Tectonophysics 236, 373-90.

Macdonald, R., Kjarsgaard, B. A., Skilling, I. P., Davies, G. R., Hamilton, D. L. \& Black, S. 1993. Liquid immiscibility between trachyte and carbonate in ash flow tuffs from Kenya. Contributions to Mineralogy and Petrology 114, 276-87.

Macdonald, R., Navarro, J.-M., Upton, B. G. J. \& Davies, G. R. 1994a. Strong compositional zonation in peralkaline magma; Menengai, Kenya Rift valley. Journal of Volcanology and Geothermal Research 60, 301-25. 
Macdonald, R., Williams, L. A. J. \& Gass, I. G. 1994b. Tectonomagmatic evolution of the Kenya rift valley: some geological perspectives. Journal of the Geological Society, London 151, 879-88.

Macdonald, R., Davies, G. R., Upton, B. G. J., Dunkley, P. N., Smith, M. \& Leat, P. T. 1995. Petrogenesis of Silali volcano, Gregory Rift, Kenya. Journal of the Geological Society, London 152, 703-20.

Macdonald, R., Rogers, N. W., Fitton, J. G., Black, S. \& Smith, M. 2001. Plume-lithosphere interactions in the generation of the basalts of the Kenya Rift, East Africa. Journal of Petrology 42, $877-900$.

Marty, B., Pik, R. \& Yirgu, G. 1996. Helium isotopic variations in Ethiopian plume lavas: nature of magmatic sources and limit on lower mantle contribution. Earth and Planetary Science Letters 144, 223-37.

Mechie, J., Keller, G. R., Prodehl, C., Gaciri, S., Braile, L. W., Mooney, W. D., Gajewski, D. \& Sandmeier, K.-J. 1994. Crustal structure beneath the Kenya Rift from axial profile data. Tectonophysics 236, 179-200.

Mechie, J., Keller, G. R., Prodehl, C., Khan, M. A. \& Gaciri, S. J. 1997. A model for the structure, composition and evolution of the Kenya rift. Tectonophysics 278, 95-119.

Mooney, W. D. \& Christensen, N. I. 1994. Composition of the crust beneath the Kenya rift. Tectonophysics 236, 391-408.

Morley, C. K., Westcott, W. A., Stone, D. M., Harper, R. M., Wigger, S. T. \& Karanja, F. M. 1992. Tectonic evolution of the northern Kenya Rift. Journal of the Geological Society, London 149, 333-48.

Mussett, A. E. \& Khan, M. A. 2000. Looking Into The Earth: An Introduction to Geological Geophysics. Cambridge: Cambridge University Press.

Ni, S., Tan, E., Gurnis, M. \& Helmberger, D. 2002. Sharp sides to the African superplume. Science 296, 1850-2.

Noble, J. W. \& Ojiambo, S. B. 1975. Geothermal exploration in Kenya. Proceedings of the Second Unitd Nations Symposium on the Development and Use of Geothermal Resources, 68-72 San Francisco: United Nations.

Norry, M. J., Truckle, P. H., Lippard, S. J., Hawkesworth, C. J., Weaver, S. D. \& Marriner, G. F. 1980. Isotopic and trace element evidence from lavas, bearing on mantle heterogeneity beneath Kenya. Philosophical Transactions of the Royal Society of London A279, 259-71.

Nyblade, A. A., Owens, T. J., Gurrola, H., Ritsema, J. \& Langston, C. A. 2000. Seismic evidence for a deep upper mantle thermal anomaly beneath east Africa. Geology 28, 599-602.

Paslick, C., Halliday, A., James, D. \& Dawson, J. B. 1995. Enrichment of the continental lithosphere by OIB melts: isotopic evidence from the volcanic province of northern Tanzania. Earth and Planetary Science Letters 130, 109-26.

Price, R. C., Johnson, R. W., Gray, C. M. \& Frey, F. A. 1985. Geochemistry of phonolites and trachytes from the summit region of Mt. Kenya. Contributions to Mineralogy and Petrology 89, 394 409.

Prodehl, C., Keller, G. R. \& Khan, M. A. (eds.) 1994. Crustal and upper mantle structure of the Kenya Rift. Tectonophysics 236, 1483.

Rehkämper, M., Halliday, A. N., Barfod, D., Fitton, J. G. \& Dawson, J. B. 1997. Platinum-group element abundance patterns in different mantle environments. Science 278, 1595-8.

Ritsema, J., van Heijst, H. J. \& Woodhouse, J. H. 1999. Complex shear wave velocity structure imaged beneath Africa and Iceland. Science 286, 1925-8.

Rogers, N. W., Macdonald, R., Fitton, J. G., George, R. W. W., Smith, M. \& Barreiro, B. A. 2000. Two mantle plumes beneath the East African rift system: $\mathrm{Sr}, \mathrm{Nd}$ and $\mathrm{Pb}$ isotope evidence from Kenya Rift basalts. Earth and Planetary Science Letters 176, 387400 .
Rudnick, R. L., McDonough, W. F. \& Chappell, B. W. 1993. Carbonatite metasomatism in the northern Tanzanian mantle: petrographic and geochemical characteristics. Earth and Planetary Science Letters 114, 463-75.

Scaillet, B. \& Macdonald, R. 2001. Phase relations of peralkaline silicic magmas and petrogenetic implications. Journal of Petrology 42, 825-45.

Sceal, J. S. C. \& Weaver S. D. 1971. Trace element data bearing on the origin of salic rocks from the Quaternary volcano Paka, Gregory Rift, Kenya. Earth and Planetary Science Letters 12, 327-31.

Scott, S. C. 1982. Evidence from Longonot volcano, Central Kenya, lending further support to the argument for a coexisting $\mathrm{CO}_{2}$-rich vapour in peralkaline magma. Geological Magazine 19, 215-7.

Scott, S. C. \& Skilling, I. P. 1999. The role of tephrachronology in recognising synchronous caldera-forming events at the Quaternary volcanoes Longonot and Suswa, south Kenya Rift. In Firth, C.R \& McGuire, W. J. (eds) Volcanoes in the Quaternary, Geological Society, London, Special Publication 161, 47-67. London: Geological Society.

Simiyu, S. M. \& Keller, G. R. 1997 An integrated analysis of lithospheric structure across the East African plateau based on gravity anomalies and recent seismic studies. Tectonophysics $\mathbf{2 7 8}$, 291-313.

Slack, P. D., Davis, P. M. \& the KRISP Teleseismic Working Group 1994. Attenuation and velocity of P-waves in the mantle beneath the East African Rift, Kenya. Tectonophysics 236, 331-58.

Smith, M. 1994. Stratigraphic and structural constraints on mechanisms of active rifting in the Gregory Rift, Kenya. Tectonophysics 236, 3-22.

Smith, M. \& Mosley, P. 1993. Crustal heterogeneity and basement influence on the development of the Kenya rift, East Africa. Tectonics 12, 591-606.

Späth, A., le Roex, A. P. \& Opiyo-Akech, N. 2000. The petrology of the Chyulu Hills Volcanic Province. Journal of African Earth Sciences 31, 337-58.

Späth, A., le Roex, A. P. \& Opiyo-Akech, N. 2001. Plume-lithosphere interaction and the origin of continental rift-related alkaline volcanism - the Chyulu Hills Volcanic Province, southern Kenya. Journal of Petrology 42, 765-87.

Sun, S.-S. \& McDonough, W. F. 1989. Chemical and isotopic systematics of oceanic basalts: implications for mantle composition and processes. In Saunders, A. D. \& Norry, M. J. (eds) Magmatism in the Ocean Basins, Geological Society, London, Special Publication 42, 313-45. London: Geological Society.

Suwa, K., Yusa, Y. \& Kishida, N. 1975. Petrology of peridotite nodules from Ndonyuo Olnchoro, Samburu District, central Kenya. Physics and Chemistry of the Earth 9, 273-86.

Swain, C. J. 1992. The Kenya rift axial gravity high; a reinterpretation. Tectonophysics 204, 59-70.

Truckle, P. H. 1980. Variation of basic lava petrology of the Kenya rift valley. In Carelli, A. (Pres.), Geodynamic Evolution of the AfroArabic Rift System 133-42. Rome: Accademia Nazionale dei Lincei.

Turner, S., Hawkesworth, C. J., Gallagher, K., Stewart, K., Peate, D. W. \& Mantovani, M. 1996. Mantle plumes, flood basalts, and thermal models for melt generation beneath continents: assessment of a conductive heating model and application to the Paraná. Journal of Geophysical Research 101, 11503-18.

Weaver, S. D. 1997. The Quaternary caldera volcano Emuruangogolak, Kenya Rift, and the petrology of a bimodal ferrobasalt-pantelleritic trachyte association. Bulletin Volcanologique 40, 209-30.

Williams, L. A. J. 1972. The Kenya rift volcanics: a note on volumes and chemical composition. Tectonophysics 15, 83-96.

Zhao, D. 2001. Seismic structure and origin of hotspots and mantle plumes. Earth and Planetary Science Letters 192, 251-65.

RAY MACDONALD, Environmental Sciences Department, Lancaster University, Lancaster LA1 4YQ, U.K.

MS received 9 July 2002. Accepted for publication 12 December 2002. 